\title{
Synthesis of Bacterial Urease Flap Region Peptide Equivalents and Detection of Rheumatoid Arthritis Antibodies Using Two Methods
}

\author{
Iwona Konieczna ${ }^{1} \cdot$ Beata Kolesińska ${ }^{2}$ Joanna Gleńska-Olender ${ }^{1} \cdot$ Grzegorz Czerwonka $^{1} \cdot$ Inga Relich $^{2}$ • \\ Justyna Frączyk ${ }^{2}$ - Zbigniew J. Kamiński ${ }^{2}$. Wiesław Kaca' ${ }^{1}$ (1)
}

Accepted: 21 January 2019 / Published online: 26 February 2019

(C) The Author(s) 2019

\begin{abstract}
Rheumatoid arthritis (RA) is an autoimmune inflammatory disease that leads to cartilage damage, joint destruction and bone erosions. Serological analysis is one of the most important tools for diagnosis of RA. The aims of studies were the synthesis of an amino-acid library of epitope CHHLDKSIKEDVQFADSRI corresponding to the flap region of $\mathrm{H}$. pylori urease and investigation recognition by serum antibodies from one rheumatoid arthritis patient (RAP) and one volunteer blood donor (VBD) tested by two semi-quantitative methods. In this study we compared two immunoblot variants for estimation of antibodies recognizing five synthetic peptides corresponding to the urease flap region sequence from different organisms. One immunoblot variant was a classic dot-blot using HRP-conjugated anti-human antibodies, where the level of bound immunoglobulins was estimated by digitization of color formed by reaction with secondary antibody. The second immunoblot variant was based on fluorescein-conjugated anti human antibodies. Both semi-quantitative methods were effective for evaluation of antibodies, and their advantages and disadvantages are discussed. To identify the amino-acid residues critical for reaction with antibodies, an amino-acid scan of the complete sequence of the flap region from Helicobacter pylori urease (epitope BK-61B) was conducted. Each sub-library (1-19) contained 19 peptides, each with different amino acids (a-w) at defined positions. All components of the library were synthesized using a divergent strategy. Patterns of serological reaction with the peptide library were unique for each serum sample from an RA patient or control blood donor. The amino-acid residues in epitope BK-61B necessary for strong reaction with antibodies and preventing reaction with antibodies were identified.
\end{abstract}

Keywords Urease flap region peptides $\cdot$ Rheumatoid arthritis antibody detection

$\begin{array}{ll}\text { Abbreviations } \\ \text { RA } & \text { Rheumatoid arthritis } \\ \text { DCMT } & \text { 2,4-Dichloro-6-methoxy-1,3,5-triazine } \\ \text { RAP } & \text { Rheumatoid arthritis serum } \\ \text { VBD } & \text { Volunteer blood donors serum }\end{array}$

Wiesław Kaca

wieslaw.kaca@ujk.edu.pl

1 Department of Microbiology, Institute of Biology, Jan Kochanowski University, Swietokrzyska 15 str. 25-406 Kielce, Poland

2 Institute of Organic Chemistry, Lodz University of Technology, Lodz, Poland

\section{Introduction}

Rheumatoid arthritis (RA) is an autoimmune inflammatory disease. Without treatment, inflammation leads to cartilage damage, joint destruction and bone erosions. RA causes permanent disability (Agarwal 2011). There are suggestions that infectious agents such as viruses (Epstein-Barr virus, parvovirus) and bacteria (Proteus, Mycoplasma) may be connected with the development of RA (Silman and Pearson 2002). All of these agents are able to activate the RA patient's immune system. Especially strong stimulation of antibody synthesis was observed in the case of Proteus sp. proteins, which have cytotoxic effects on joint tissues (Rashid et al. 2007).

Serological analysis is one of the most important tools for diagnosis of RA. The markers of RA are anti-cyclic citrullinated peptide (anti-CCP) and autoantibodies such as rheumatoid factor (RF) (Pincus and Sokka 2009; Corrao et al. 2011; Aletaha et al. 2010). However, these markers 
are not detected in about one-third of patients (Somers et al. 2011). On the other hand, it is known that inflammatory reactions (organ specific and non-specific) contribute to chronic disease (van Eden et al. 2002). Additionally, the immune systems of individuals suffering from inflammation are unstable. The resulting antibodies are not specific and may recognize antigens with similar sequences as well as the correct antigens (Konieczna et al. 2012). Detection of antibodies may be realized using different techniques. Methods based on peroxidase-labeled immunoglobulin are the most commonly used (Moelants et al. 2011; Somers et al. 2011). However, techniques that employ antibodies conjugated with fluorescent dyes are also used (Copse and Fowler 2002; Gingrich et al. 2000; Morseman et al. 1999).

Synthetic peptides are useful tools in immunological studies. Using sets of peptides with truncated amino acid sequences has enabled epitope mapping of several bacterial ureases (Arabski et al. 2010; Kamiński et al. 2006; Reimer et al. 2011). Tiwana et al. used synthetic peptides (ESRRAL from Proteus mirabilis hemolysin and EQKRAA, an RA susceptibility motif) for molecular mimicry investigations (Tiwana et al. 1999). Several synthetic peptides corresponding to flap fragments of ureases from different organisms have been used for determination of the levels and specificities of antibodies in RA patients (Konieczna et al. 2012; Arabski et al. 2010).

In earlier studies we revealed that Helicobacter pylori Ure A fragments 11-24, 21-33, and 31-42 were able to interact with Jack bean urease antibodies (Kaminski et al. 2018).

The aims of these studies were:

- synthesis of an amino-acid scan library of epitope CHHLDKSIKEDVQFADSRI corresponding to the flap region of $H$. pylori urease;

- investigation of the effect of replacing every amino acid residue in $H$. pylori urease flap fragment with all proteinogenic amino acids on recognition by serum antibodies from one rheumatoid arthritis patient (RAP) and one volunteer blood donor (VBD);

- comparison of sensitivities and specificities of two methods of semi-quantitative dot-blot.

\section{Materials and Methods}

\section{Subjects}

Human sera: serum from a rheumatoid arthritis patient (age 41 years, female) and serum from a volunteer blood donor (age 40 years, female) were used. RAP serum was from Edmund Biernacki District Hospital in Mielec, Poland. The normal control VBD serum was from the Swietokrzyskie Blood Center, Kielce, Poland.
In this study, five synthetic oligopeptides corresponding to the flap region of ureases from different organisms (BK-61A: SIKEDVQF and BK-61B: CHHLDKSIKEDVQFADSRI-characteristic of $H$. pylori; BK-65B: MLMVCHHLDPSIPEDVA—characteristic of Proteus sp.; BK-65C: MVMITHHLNASIPEDIA-characteristic of Staphylococcus sp. and BK-65D: MLMVCHHLNREIPEDIA-similar to Canavalia ensiformis) were used.

\section{Synthesis of Peptides: BK-65B, BK-65C, and BK-65D Immobilized on Cellulose}

\section{Immobilization of 2,4-Dichloro-6-methoxy-1,3,5-triazine (DCMT) on Cellulose}

Whatman 7 filter paper $(5 \times 10 \mathrm{~cm})$ was treated with $1 \mathrm{M}$ $\mathrm{NaOH}(25 \mathrm{~mL})$ for $15 \mathrm{~min}$ and then the excess liquid was removed. A solution of DCMT $(1 \mathrm{~g}, 5.59 \mathrm{mM})$ in THF $(25 \mathrm{~mL})$ and solid $\mathrm{NaHCO}_{3}(0.5 \mathrm{~g}, 5.95 \mathrm{mM})$ were then added and the reagents were shaken for $40 \mathrm{~min}$. The filter paper was washed with $50 \%$ aqueous THF $(25 \mathrm{~mL})$, water $(25 \mathrm{~mL})$, and THF $(3 \times 25 \mathrm{~mL})$ until color reaction of the filtrate with 4-(4'nitrobenzyl)pyridine (characteristic for DCMT, Preussmann et al. 1969) was not detected in the washing aliquot, and then dried in a desiccator (see scheme at Fig. 1).

Loading of the cellulose plate with triazine was calculated from elemental analysis data.

According to nitrogen content of $2.60 \mathrm{mmol}(\mathrm{N}) \mathrm{g}^{-1}$, the calculated loading was equivalent to ${ }^{\mathrm{N}} \mathrm{Lw}=0.87 \mathrm{mmol}$ (triazine) $\mathrm{g}^{-1}$. The surface loading was calculated according to nitrogen content of $31.9 \times 10^{-6} \mathrm{~mol}(\mathrm{~N}) \mathrm{cm}^{-2}$, which was equivalent to ${ }^{\mathrm{N}} \mathrm{Ls}=10.6 \times 10^{-6} \mathrm{~mol}$ (triazine) $\mathrm{cm}^{-2}$. According to the chlorine content, the calculated loading was ${ }^{\mathrm{Cl}} \mathrm{Lw}=0.75 \mathrm{mmol}(\mathrm{Cl}) \mathrm{g}^{-1}$, which was equivalent to ${ }^{\mathrm{Cl}} \mathrm{Ls}=9.2 \times 10^{-6} \mathrm{~mol}(\mathrm{Cl}) \mathrm{cm}^{-2}$.

\section{Immobilization of Alanine on the Cellulose Plate}

The cellulose plate with immobilized DCMT was treated with a $1 \mathrm{M}$ solution of 4-methylmorpholine (NMM, $1.1 \mathrm{~mL}$, $10 \mathrm{mM})$ in THF $(10 \mathrm{~mL})$ and shaken for $30 \mathrm{~min}$. The plate was then washed with THF $(3 \times 10 \mathrm{~mL})$, treated with a solution of Fmoc-Ala-OH $(1.556 \mathrm{~g}, 5 \mathrm{mM})$ and NMM $(0.55 \mathrm{~mL}$, $5 \mathrm{mM}$ ) in dichloromethane (DCM, $20 \mathrm{~mL}$ ) for $4 \mathrm{~h}$, washed with DCM $(5 \times 10 \mathrm{~mL})$, and then the excess solvent was removed. The plate was immersed in dry boiling toluene for $6 \mathrm{~h}$ and then dried thoroughly in a vacuum desiccator (Kaminski et al. 2018). The Fmoc group was removed by treatment with a $25 \%$ solution of piperidine in dimethyl formamide (DMF, $20 \mathrm{~mL}$ ) for $15 \mathrm{~min}$ followed by washing with DMF $(2 \times 10 \mathrm{~mL})$ and DCM $(2 \times 10 \mathrm{~mL})$. 

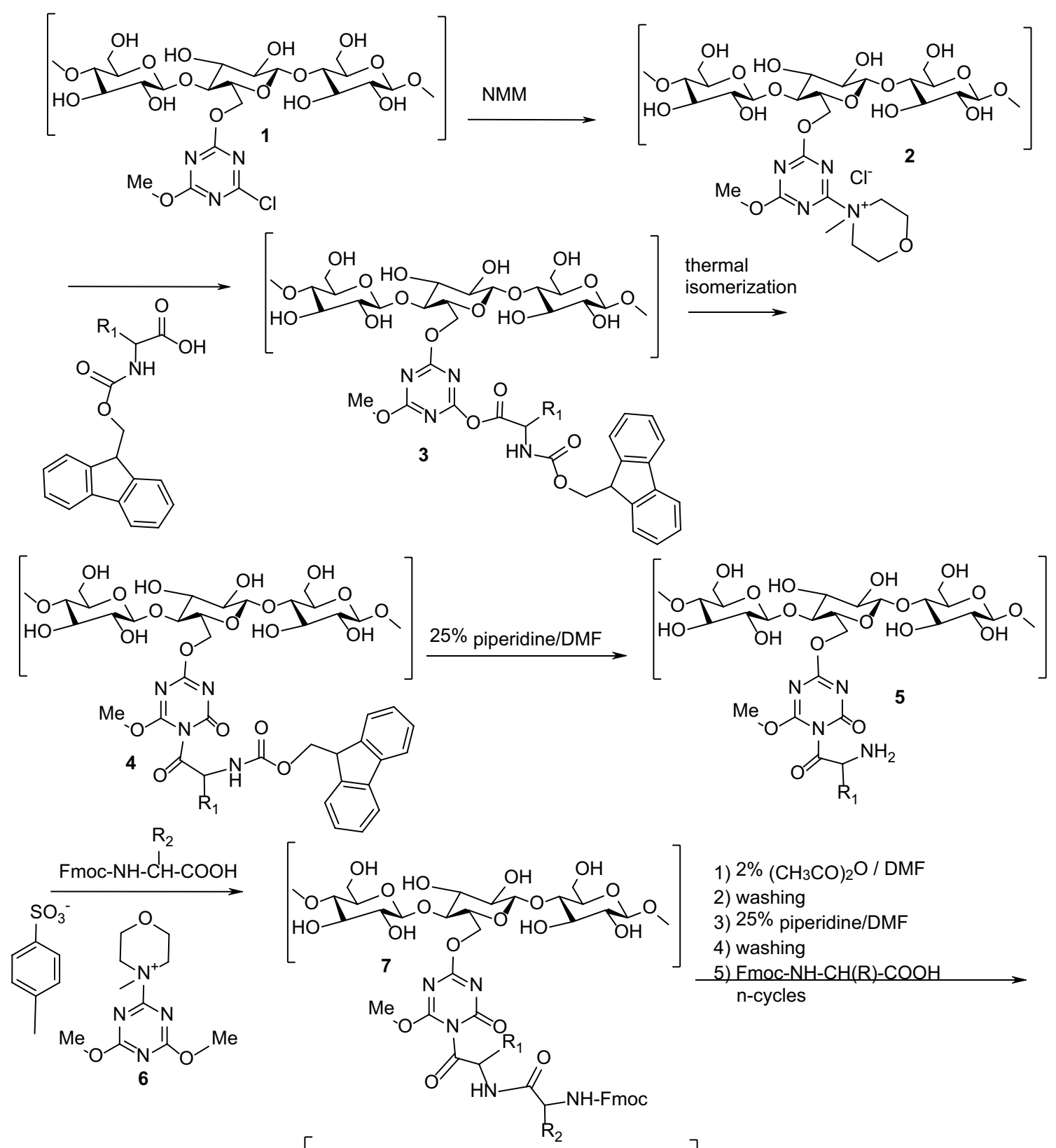

1) $2 \%\left(\mathrm{CH}_{3} \mathrm{CO}\right)_{2} \mathrm{O} / \mathrm{DMF}$

2) washing

3) $25 \%$ piperidine/DMF

4) washing

5) $\mathrm{Fmoc}-\mathrm{NH}-\mathrm{CH}(\mathrm{R})-\mathrm{COOH}$

n-cycles

$\operatorname{TFA} \mathrm{DCM}(1: 1)$

$\overrightarrow{3 \% \mathrm{TRIS}+2 \% \mathrm{H}_{2} \mathrm{O}}$

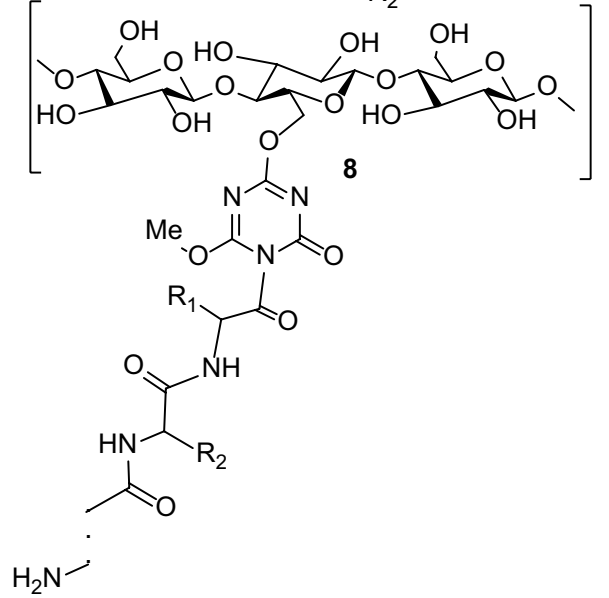

Fig. 1 Synthetic procedure used for the preparation of BK-65B, BK-65C, BK-65D and the 361 component library of oligopeptides 


\section{Synthesis of BK-65B: MLMVCHHLDPSIPEDVA Immobilized on the Cellulose Plate}

Incorporation of Fmoc-Val-OH: 4-(4,6-Dimethoxy-1,3,5triazin-2-yl)-4-methylmorpholinium toluene-4-sulfonate $\left(\mathrm{DMT} / \mathrm{NMM} / \mathrm{TsO}^{-}, 0.619 \mathrm{~g}, 1.5 \mathrm{mmol}\right)$ and $\mathrm{NMM}$ $(0.33 \mathrm{~mL}, 3 \mathrm{mmol})$ were added to a solution of FmocVal-OH $(0.509 \mathrm{~g}, 1.5 \mathrm{mmol})$ in DMF $(10 \mathrm{~mL})$. The cellulose plate with immobilized alanine on the surface was immersed into freshly prepared coupling mixture in DMF, and shaken for $2 \mathrm{~h}$.

Washing of cellulose membrane: The plate was thoroughly washed by gently shaking for $5 \mathrm{~min}$ with the following solvents: DMF $(2 \times 10 \mathrm{~mL})$ and DCM $(2 \times 10 \mathrm{~mL})$.

Deprotection of Fmoc-group: The Fmoc group was removed using $25 \%(\mathrm{v} / \mathrm{v})$ piperidine in DMF $(20 \mathrm{~mL})$ for $20 \mathrm{~min}$ and then the plate was washed with DMF $(2 \times 10 \mathrm{~mL})$ and DCM $(2 \times 10 \mathrm{~mL})$.

All subsequent steps of the synthesis included repeating cycles of incorporation of the next amino acid using Fmoc/ tBu protection, washing of the cellulose membrane, deprotection of the Fmoc group and washing as described above.

Incorporation of Fmoc-Asp(OtBu)-OH was completed according to the procedure described above. Starting materials: Fmoc-Asp(OtBu)-OH (0.617 g, $1.5 \mathrm{mmol})$, DMT/ $\mathrm{NMM} / \mathrm{TsO}^{-}(0.619 \mathrm{~g}, 1.5 \mathrm{mmol}), \mathrm{NMM}(0.33 \mathrm{~mL}, 3 \mathrm{mmol})$.

Incorporation of Fmoc-Glu(OtBu)-OH. Starting materials: Fmoc-Glu(OtBu)-OH (0.638 g, $1.5 \mathrm{mmol}), \mathrm{DMT} / \mathrm{NMM} /$ $\mathrm{TsO}^{-}(0.619 \mathrm{~g}, 1.5 \mathrm{mmol})$, NMM $(0.33 \mathrm{~mL}, 3 \mathrm{mmol})$.

Incorporation of Fmoc-Pro-OH. Starting materials: Fmoc-Pro-OH (0.506 g, $1.5 \mathrm{mmol})$, DMT/NMM/ $\mathrm{TsO}^{-}(0.619 \mathrm{~g}, 1.5 \mathrm{mmol}), \mathrm{NMM}(0.33 \mathrm{~mL}, 3 \mathrm{mmol})$.

Incorporation of Fmoc-Ile-OH. Starting materials: FmocIle-OH (0.530 g, $1.5 \mathrm{mmol})$, DMT/NMM/TsO ${ }^{-}(0.619 \mathrm{~g}$, $1.5 \mathrm{mmol})$, NMM (0.33 mL, $3 \mathrm{mmol})$.

Incorporation of Fmoc-Ser(tBu)-OH. Starting materials: Fmoc-Ser(tBu)-OH (0.575 g, $1.5 \mathrm{mmol})$, DMT/NMM/ $\mathrm{TsO}^{-}(0.619 \mathrm{~g}, 1.5 \mathrm{mmol}), \mathrm{NMM}(0.33 \mathrm{~mL}, 3 \mathrm{mmol})$.

Incorporation of Fmoc-Pro-OH. Starting materials: Fmoc-Pro-OH (0.506 g, $1.5 \mathrm{mmol})$, DMT/NMM/ $\mathrm{TsO}^{-}(0.619 \mathrm{~g}, 1.5 \mathrm{mmol}), \mathrm{NMM}(0.33 \mathrm{~mL}, 3 \mathrm{mmol})$.

Incorporation of Fmoc-Asp(OtBu)-OH. Starting materials: Fmoc-Asp(OtBu)-OH (0.617 g, $1.5 \mathrm{mmol})$, DMT/ $\mathrm{NMM} / \mathrm{TsO}^{-}(0.619 \mathrm{~g}, 1.5 \mathrm{mmol}), \mathrm{NMM}(0.33 \mathrm{~mL}, 3 \mathrm{mmol})$.

Incorporation of Fmoc-Leu-OH. Starting materials: Fmoc-Leu-OH (0.530 g, $1.5 \mathrm{mmol})$, DMT/NMM/ $\mathrm{TsO}^{-}(0.619 \mathrm{~g}, 1.5 \mathrm{mmol})$, NMM $(0.33 \mathrm{~mL}, 3 \mathrm{mmol})$.

Incorporation of Fmoc-His(Trt)-OH. Starting materials: Fmoc-His(Trt)-OH (0.929 g, $1.5 \mathrm{mmol})$, DMT/NMM/ $\mathrm{TsO}^{-}(0.619 \mathrm{~g}, 1.5 \mathrm{mmol})$, NMM $(0.33 \mathrm{~mL}, 3 \mathrm{mmol})$.

Incorporation of Fmoc-His(Trt)-OH. Starting materials: Fmoc-His(Trt)-OH (0.929 g, $1.5 \mathrm{mmol})$, DMT/NMM/ $\mathrm{TsO}^{-}(0.619 \mathrm{~g}, 1.5 \mathrm{mmol}), \mathrm{NMM}(0.33 \mathrm{~mL}, 3 \mathrm{mmol})$.
Incorporation of Fmoc-Cys(Trt)-OH. Starting materials: Fmoc-Cys(Trt)-OH (0.878 g, $1.5 \mathrm{mmol})$, DMT/NMM/ $\mathrm{TsO}^{-}(0.619 \mathrm{~g}, 1.5 \mathrm{mmol})$, NMM $(0.33 \mathrm{~mL}, 3 \mathrm{mmol})$.

Incorporation of Fmoc-Val-OH. Starting materials: Fmoc-Val-OH (0.509 g, $1.5 \mathrm{mmol})$, DMT/NMM/ $\mathrm{TsO}^{-}(0.619 \mathrm{~g}, 1.5 \mathrm{mmol})$, NMM $(0.33 \mathrm{~mL}, 3 \mathrm{mmol})$.

Incorporation of Fmoc-Met-OH. Starting materials: Fmoc-Met-OH (0.557 g, $1.5 \mathrm{mmol})$, DMT/NMM/ $\mathrm{TsO}^{-}(0.619 \mathrm{~g}, 1.5 \mathrm{mmol})$, NMM $(0.33 \mathrm{~mL}, 3 \mathrm{mmol})$.

Incorporation of Fmoc-Leu-OH. Starting materials: Fmoc-Leu-OH (0.530 g, $1.5 \mathrm{mmol})$, DMT/NMM/ $\mathrm{TsO}^{-}(0.619 \mathrm{~g}, 1.5 \mathrm{mmol})$, NMM $(0.33 \mathrm{~mL}, 3 \mathrm{mmol})$.

Incorporation of Fmoc-Met-OH. Starting materials: Fmoc-Met-OH (0.557 g, $1.5 \mathrm{mmol})$, DMT/NMM/ $\mathrm{TsO}^{-}(0.619 \mathrm{~g}, 1.5 \mathrm{mmol}), \mathrm{NMM}(0.33 \mathrm{~mL}, 3 \mathrm{mmol})$.

The side chain protecting groups were removed using a $50 \%(\mathrm{v} / \mathrm{v})$ solution of trifluoroacetic acid (TFA) in DCM $(20 \mathrm{~mL})$ containing $2 \%$ tri-isopropyl silane (TIS) and 3\% water for $4 \mathrm{~h}$. For the final washing of the plates, DCM $(3 \times 10 \mathrm{~mL})$ and $\mathrm{EtOH}(3 \times 10 \mathrm{~mL})$ were used.

To confirm the structure of the obtained product, cellulose-bound peptide was treated with $1 \mathrm{M}$ aqueous $\mathrm{LiOH}$ solution for $2 \mathrm{~h}$. The cleaved peptide was thoroughly washed from the surface of the cellulose with water and then the aqueous solution was acidified with $1 \mathrm{M} \mathrm{HCl}$ solution to $\mathrm{pH} 4-5$.

HR-MS analysis: $1908.3841\left([\mathrm{M}+\mathrm{H}]^{+}\right.$; calc. $\mathrm{C}_{82} \mathrm{H}_{132} \mathrm{~N}_{21} \mathrm{O}_{25} \mathrm{~S}_{3}{ }^{+}$1908.28) was determined on a high-resolution (HR) MS: IonSpecUltima 4.7-T-FT Ion Cyclotron Resonance (ICR; HR-MALDI, in 2,5-dihydroxybenzoic acid matrix) spectrometer. Analytical RP-HPLC (5-97\% $B$ in $30 \mathrm{~min}$ ): $t_{\mathrm{R}} 16.29 \mathrm{~min}$, purity $98.5 \%$, was performed on a Merck/Hitachi HPLC system (LaChrome; pump type, L-6200;UV detector, L-4000; interface, D-6000; HPLC manager, D-7000) using a Supelco Discovery BIO Wide Pore ${ }^{\circledR} \mathrm{C}_{18}$ column $(25 \mathrm{~cm} \times 4.6 \mathrm{~mm}, 5 \mathrm{~mm}$, Sigma). HPLC was performed with a gradient of $0.1 \%$ TFA in $\mathrm{H}_{2} \mathrm{O}(A)$ and $0.08 \% \mathrm{TFA}$ in $\mathrm{MeCN}(B)$, at a flow rate of $1 \mathrm{~mL} \mathrm{~min}^{-1}$ using UV detection at $220 \mathrm{~nm}$.

BK-65C: MVMITHHLNASIPEDIA and BK-65D: MLMVCHHLNREIPEDIA peptides were prepared according to the typical procedure described above for BK-65B.

\section{Synthesis of 361 Analogues of BK-61B Divided into 19 Sub-libraries, for Amino Acid Scan of Epitope CHHLDKSIKEDVQFADSRI. Typical Procedure}

Nineteen plates of cellulose $(8 \times 10 \mathrm{~cm})$ Whatman-7 filter paper, marked from 1 to 19 , were functionalized with DCMT (20 g, $112 \mathrm{mM}$ ) according to the procedure described above. 


\section{Synthesis of Sub-library 1}

Functionalized cellulose plate 1 was treated with a $1 \mathrm{M}$ solution of NMM $(1.65 \mathrm{~mL}, 15 \mathrm{mM})$ and Fmoc-Ile-OH $(1.767 \mathrm{~g}, 5 \mathrm{mM})$, and then washed according to the procedure described above. The Fmoc group was removed from the attached isoleucine by treatment with a $25 \%$ solution of piperidine in DMF $(20 \mathrm{~mL})$ for $15 \mathrm{~min}$ followed by washing with DMF $(2 \times 10 \mathrm{~mL})$ and DCM $(2 \times 10 \mathrm{~mL})$.

All subsequent steps of the synthesis included consecutively repeated cycles:

(1) condensation: in all steps the coupling reagent DMT/ $\mathrm{NMM} / \mathrm{TsO}^{-}$(1.239 g, $3 \mathrm{mmol}$ ) was used with an equivalent amount of Fmoc-protected amino acid and NMM (0.66 mL, $6 \mathrm{mmol})$;

(2) washing: the plate was thoroughly washed with DMF $(2 \times 10 \mathrm{~mL})$ and DCM $(2 \times 10 \mathrm{~mL})$;

(3) deprotection of Fmoc group: the Fmoc group was removed using 25\% (v/v) piperidine in DMF $(20 \mathrm{~mL})$ for $20 \mathrm{~min}$;

(4) washing: the plate was washed with DMF $(2 \times 10 \mathrm{~mL})$ and DCM $(2 \times 10 \mathrm{~mL})$.

The following protected amino acids were used: Fmoc-Arg(Pbf)-OH (1.946 g, 3 mmol); Fmoc-Ser(tBu)$\mathrm{OH}(1.150 \mathrm{~g}, 3 \mathrm{mmol})$; Fmoc-Asp(OtBu)-OH (1.234 g, 3 mmol); Fmoc-Ala-OH (0.934 g, 3 mmol); Fmoc-Phe$\mathrm{OH}$ (1.162 g, 3 mmol); Fmoc-Gln(Trt)-OH (1.832 g, 3 mmol); Fmoc-Val-OH (1.018 g, 3 mmol); Fmoc-Asp(OtBu)-OH (1.234 g, 3 mmol); Fmoc-Glu(OtBu)-OH (1.276 g, $3 \mathrm{mmol})$; Fmoc-Lys(Boc)-OH (1.405 g, $3 \mathrm{mmol})$; Fmoc-Ile-OH (1.060 g, $3 \mathrm{mmol})$; Fmoc$\mathrm{Ser}(\mathrm{tBu})-\mathrm{OH}$ (1.150 g, 3 mmol); Fmoc-Lys(Boc)-OH (1.405 g, $3 \mathrm{mmol})$; Fmoc-Asp(OtBu)-OH (1.234 g, $3 \mathrm{mmol})$; Fmoc-Leu-OH (1.060 g, $3 \mathrm{mmol})$; FmocHis(Trt)-OH (1.859 g, 3 mmol), and Fmoc-His(Trt)$\mathrm{OH}(1.859 \mathrm{~g}, 3 \mathrm{mmol})$. After the final Fmoc deprotection step and washing of the modified cellulose matrix, the plate was divided into 19 parts and each fragment was marked from $1 \mathrm{a}$ to $1 \mathrm{w}$.

All natural amino acids were exploited in the last step of the synthesis of sub-library 1 . Condensation was performed using DMT/NMM/TsO ${ }^{-}(0.138 \mathrm{~g}, 0.5 \mathrm{mmol})$, equivalent amounts of Fmoc-protected amino acid, and NMM $(0.11 \mathrm{~mL}, 1 \mathrm{mmol})$.

1a: Fmoc-Ala-OH (0.156 g, 0.5 mmol), 1b: FmocVal-OH $(0.170 \mathrm{~g}, 0.5 \mathrm{mmol}) ; 1 \mathrm{c}$ : (Fmoc-Leu-OH $(0.177 \mathrm{~g}, 0.5 \mathrm{mmol})$; 1d: Fmoc-Ile-OH $(0.177 \mathrm{~g}$, $0.5 \mathrm{mmol})$; 1e: Fmoc-Phe-OH (0.194 g, $0.5 \mathrm{mmol})$; 1f: Fmoc-Tyr(tBu)-OH (0.230 g, 0.5 mmol); $1 \mathrm{~g}$ : FmocThr(tBu)-OH (0.199 g, 0.5 mmol); 1h: Fmoc-Ser(tBu)OH (0.192 g, 0.5 mmol); 1i: Fmoc-Met-OH (0.186 g, $0.5 \mathrm{mmol})$; 1j: Fmoc-Asp(OtBu)-OH (0.206 g,
$0.5 \mathrm{mmol})$; $1 \mathrm{k}$ : Fmoc-Glu(OtBu)-OH $(0.213 \mathrm{~g}$, $0.5 \mathrm{mmol})$; 11: Fmoc-Asn(Trt)-OH (0.298 g, $0.5 \mathrm{mmol}$ ); $1 \mathrm{~m}$ : Fmoc-Gln(Trt)-OH (0.305 g, $0.5 \mathrm{mmol}) ; 1 \mathrm{n}$ : Fmoc-Lys(Boc)-OH (0.234 g, $0.5 \mathrm{mmol})$; 1o: FmocHis(Trt)-OH (0.310 g, 0.5 mmol); 1p: Fmoc-Arg(Pbf)$\mathrm{OH}(0.324$ g, $0.5 \mathrm{mmol})$; 1q: Fmoc-Trp(Boc)-OH (0.263 g, $0.5 \mathrm{mmol})$; $1 \mathrm{u}$ : Fmoc-Pro-OH (0.169 g, $0.5 \mathrm{mmol})$; 1w: Fmoc-Gly-OH (0.149 g, $0.5 \mathrm{mmol})$.

All of the components $1 \mathrm{a}-1 \mathrm{w}$ of sub-library 1 were combined and thoroughly washed with DMF $(2 \times 10 \mathrm{~mL})$ and DCM $(2 \times 10 \mathrm{~mL})$.

(5) Deprotection of Fmoc-group: The Fmoc group was removed using $25 \%(\mathrm{v} / \mathrm{v})$ piperidine in DMF $(20 \mathrm{~mL})$ for $20 \mathrm{~min}$ and then the plate was washed with DMF $(2 \times 10 \mathrm{~mL})$ and DCM $(2 \times 10 \mathrm{~mL})$.

(6) Deprotection of side chain protecting groups: The side chain protecting groups were removed using a $50 \%$ $(\mathrm{v} / \mathrm{v})$ mixture of TFA in DCM $(20 \mathrm{~mL})$ with $2 \%$ TIS and $3 \%$ water for $4 \mathrm{~h}$. DCM $(3 \times 10 \mathrm{~mL})$ and $\mathrm{EtOH}$ $(3 \times 10 \mathrm{~mL})$ were used for the final washing.

See materials for the syntheses of sub-libraries 2-19.

HR-MS analysis of selected oligopeptides from sublibraries 2-19 were conducted on high-resolution (HR) MS using an IonSpecUltima 4.7-T-FT Ion Cyclotron Resonance (ICR; HR-MALDI, in 2.5-dihydroxybenzoic acid matrix) spectrometer.

\section{Serological Assays}

Classic dot-blot technique-assay was performed as described previously (Konieczna et al. 2012).

Fluorescent dot-blot technique-cellulose membrane with immobilized synthetic peptides were cut into small round discs (diameter $5 \mathrm{~mm}$ ), placed in wells of a 96-well microtiter plate (FluoroNunc ${ }^{\mathrm{TM}}$, Nunc) and incubated overnight at room temperature with shaking in blocking buffer (3\% BSA (w/v) in Tris-NaCl, $\mathrm{pH}$ 7.45). The blocking buffer was discarded and samples were incubated with human serum diluted from 1:1000 to 16,000 in $1 \%$ blocking buffer for $3 \mathrm{~h}$ (room temperature, with shaking). The serum was then removed and the membrane was washed twice with washing buffer $(0.4 \%$ Tween $80(\mathrm{v} / \mathrm{v})$ in Tris-NaCl, $\mathrm{pH} 7.45)$ and once with dot-blot buffer (Tris- $\mathrm{HCl} 0.05 \mathrm{M}, \mathrm{NaCl} 0.2 \mathrm{M}$, $\mathrm{pH}$ 7.45) each time for 5 min with shaking. Dot-blot buffer was discarded and the cellulose membranes were incubated for $1 \mathrm{~h}$ (room temperature, with shaking) with anti-human FITC antibodies (Sigma), diluted 1:1000 in 1\% blocking buffer. Membranes were washed tree times with dot-blot buffer and fluorescence was measured (Infinite 200 PRO, Tecan). Controls that were used in both methods-cellulose pure membrane with human (I-st) and labeled rabbit antibodies (II-end), cellulose support with peptides antigens plus 
I-st antibodies, and cellulose membrane with peptides plus II-end antibodies. For the final tests, cellulose membrane with peptides plus I-st and II-end antibodies were used. In the presented results, non-specific control reaction was subtracted from the digitized scan as well as from the fluorescence measurement.

\section{Results}

H. pylori urease epitopes BK-61A (SIKEDVQF) and BK61B (CHHLDKSIKEDVQFADSRI) immobilized on cellulose were obtained as described previously (Arabski et al. 2010). For the synthesis of peptides, 4-(4,6-dimethoxy-1,3,5-triazin-2-yl)-4-methylmorpholinium toluene4-sulfonate (DMT/NMM/TsO ${ }^{-}$) was used as a coupling reagent.

Previous studies revealed a statistically important difference in reactivity of BK-61A-B and BK65B-D epitopes with sera from a representative cohort of VBD and RAP patients (Konieczna et al. 2012).

Comparison of the BK-61A-B and BK65B-D sequences in flap region epitopes from different ureases (bacterial and plant origin) identified fragments with conservative (bold) and divergent amino acid residues:

BK-61A: SIKEDVQF $H$. pylori;

BK-61B: CHHLDKSIKEDVQFADSRI $H$. pylori;

BK-65B: MLMVCHHLDPSIPEDVA Proteus

BK-65C: MVMITHHLNASIPEDIA Staphylococcus

BK-65D: MLMVCHHLNREIPEDIA C. ensiformis

Two variants of the dot-blot method were used to determine levels of anti-urease antibodies. A classic dot-blot (using anti-human antibodies conjugated with horseradish peroxidase) and fluorescent dot-blot (using anti-human antibodies conjugated with fluorescein) methods were employed. The optimal incubation time for human sera and membranes with immobilized peptides was established by comparison of 1, 2, 3 and $4 \mathrm{~h}$ incubations (data not shown). For subsequent studies, $3 \mathrm{~h}$ incubation of human sera with synthetic antigens was chosen as the most reproducible.

Both variants of the dot-blot technique (classical and fluorescent) were compared using different dilutions of human sera. In each assay, one VBD serum sample and one RAP serum sample were used. Both sera were obtained from 40 year old females. The reactions of antibodies in human serum (RAP and VBD) with all 5 peptides were observed using both methods (Fig. 2.) Reaction with antibodies was visible on both sides of the cellulose membrane with immobilized peptides, despite the use of dot-blot methods. However, in all cases, the observed reactions were stronger on one side (data not shown) and those reactions were considered significant (Fig. 1).
Irrespective of dilution, RAP serum showed higher amount of antibody binding to all five oligopeptides compared to VBD when using the classic dot-blot method. In the fluorescent dot-blot, stronger reaction of RAP serum over VBD was observed for reaction with BK-65B, BK-65C and BK-65D peptide in 1:8000 and 1:16 000 serum dilutions (Fig. 2b).

The analysis of membrane surface scans after assay using the classic dot-blot method revealed heterogeneity of reaction with VBD and RAP sera. (Fig. 3).

To identify amino-acid residues vital for reaction with antibodies, peptide libraries based on the flap region sequence of $H$. pylori urease (epitope BK-61B) were synthesized. Each sub-library (1-19) contained 19 peptides (a-w), each containing one residue at a defined position substituted systematically with all proteinogenic amino acids. The systematic substitution of one amino-acid residue in each sub-library (1-19) by the complete set of 19 other aminoacids yielded a library of 361 analogues of epitope BK-61B immobilized on the cellulose support. All components of the library were synthesized using a divergent strategy. The list of substitutions is depicted in Tables 1 and 2.

To confirm the structures of the synthesized compounds, peptides were cleaved from 18 randomly selected membranes by treatment with $1 \mathrm{M} \mathrm{LiOH}$ and their structures were analyzed by HR-MS. The analytical results confirmed the structures of all selected peptides (Table 3).

The library of analogues of $H$. pylori urease epitope CHHLDKSIKEDVQFADSRI with every amino-acid residue systematically replaced by all other proteinogenic amino acids was treated with sera from one VBD and one RA patient. The reactions of the tested sera with the peptide library were assayed using a fluorescent dot-blot method. The reason for using only the fluorescence method was because it enables direct quantification in contrast to the indirect classical dot-blot procedure, which requires interactions with secondary antibodies, coloration, scanning and processing of data using the ImageJ program. The results obtained in the assay of native peptide $H$. pylori urease (epitope BK-61B) are presented in Fig. 2b.

The reaction of $361 \mathrm{H}$. pylori urease epitope BK-61B analogues with VBD and RA patient sera revealed that RA patient serum reacts with synthetic antigens differently compared with control blood donor serum. RA patient serum was substantially more tolerant towards epitope modification at position 13 than VBD serum. Both sera were insensitive to modification of epitope structure at position 12. Small differences in response were found to be caused by modification at positions 1, 2, 4-9 and 15 . The strongest and most diverse reactions resulted from modification of amino acid residues at positions 3 and 16-19 (Fig. 4). 
A
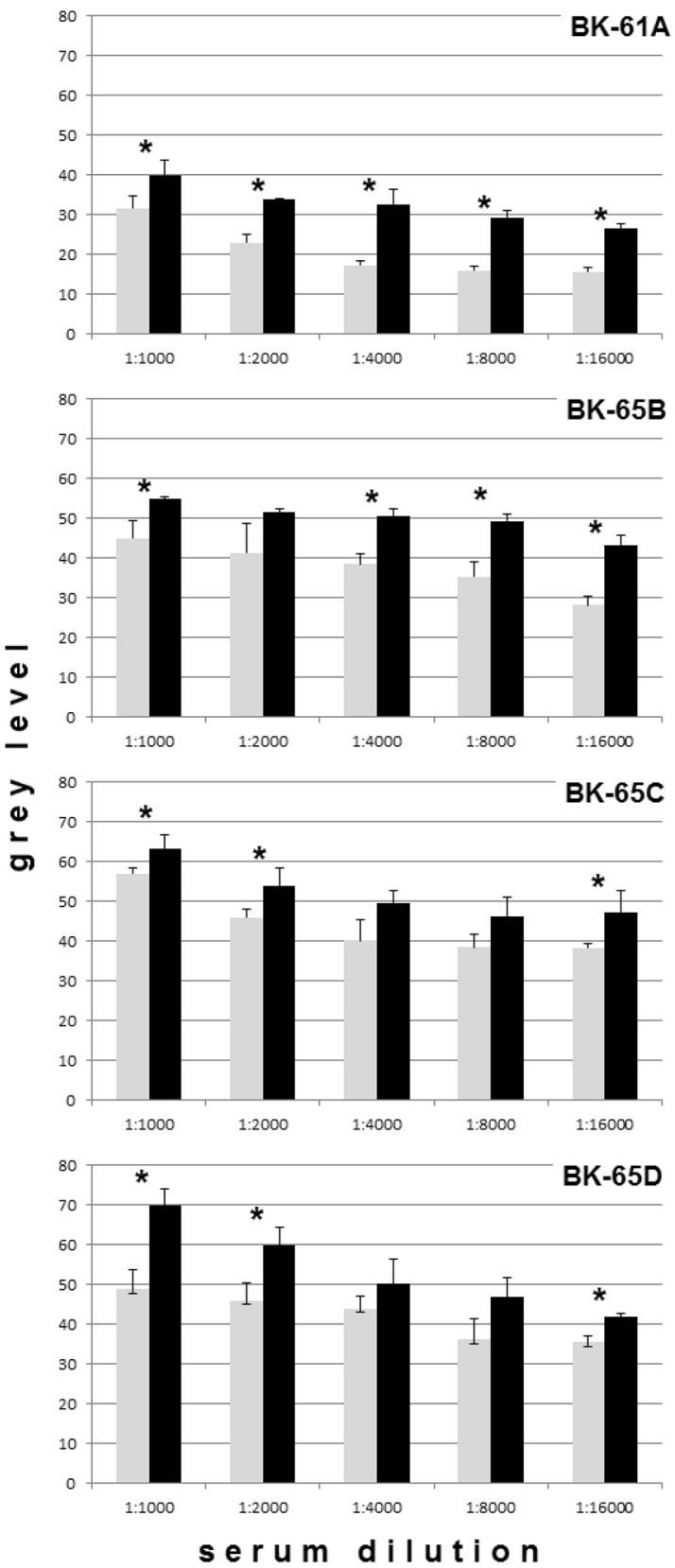

Fig. 2 The level of reaction of VBD serum (grey bars) and RAP serum (black bars) with synthetic oligopeptides corresponding to urease flap epitopes from different organisms. a classic dot-blot method;

An analysis of the variance of antibody reactions with the peptide sub-libraries (one sub-library containing populations of peptides where a defined amino acid in the original flap urease sequence was systematically substituted), confirmed their different affinity towards RAP and VBD sera (Table 4).
B
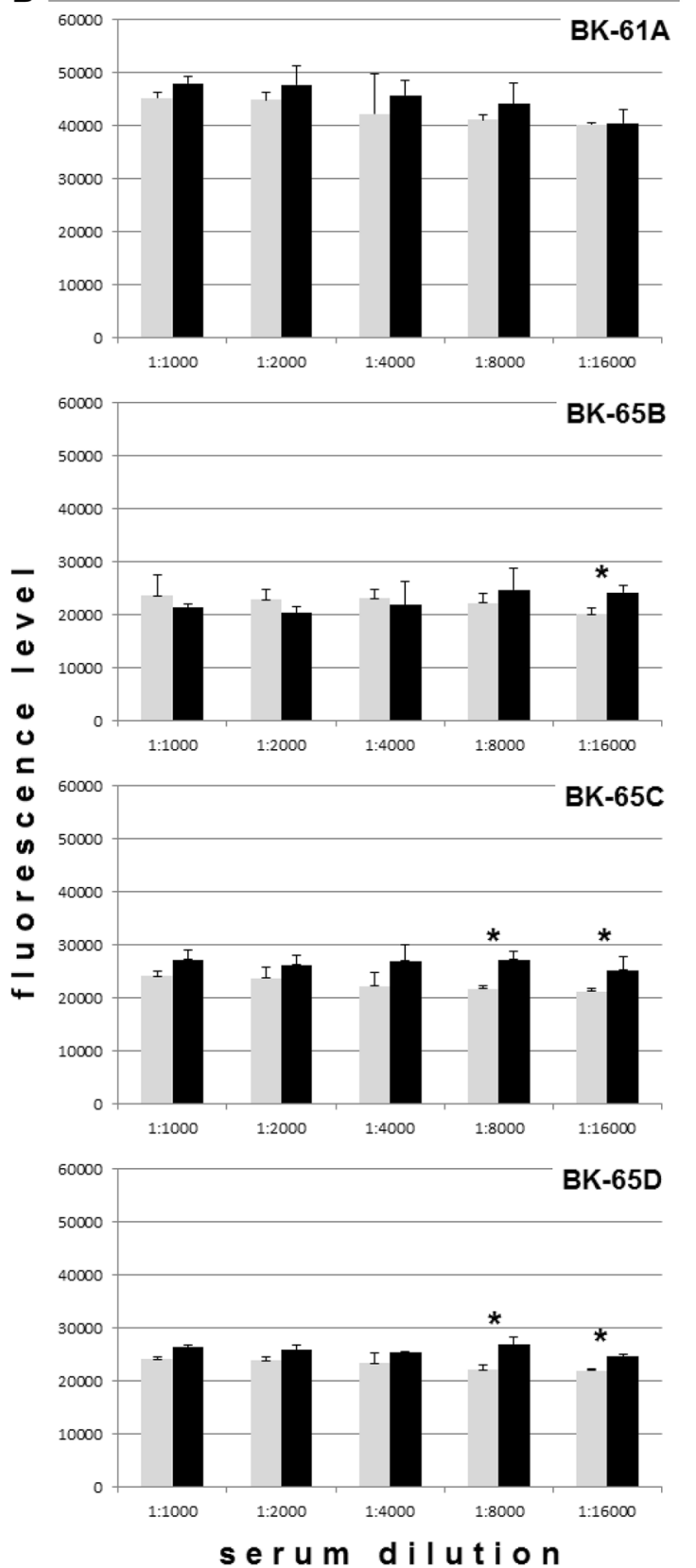

b fluorescent dot-blot method. *Statistically significant difference (one way ANOVA)

\section{Discussion}

Rheumatoid arthritis is an autoimmune disease associated with various autoantigens, but its diagnosis is still problematic (Aletaha et al. 2010; Mackenzie and Dawson 2005; Bas et al. 2002). In RA patients, instability of the immune 
Fig. 3 Heterogeneity of reaction (coloration determined using the ImageJ program) of cellulose membrane coated with synthetic peptide (BK 61B) with $\operatorname{VBD}(\mathbf{a})$ and $\operatorname{RAP}(\mathbf{b})$ sera determined using a classic variant of the semi-quantitative dot-blot method
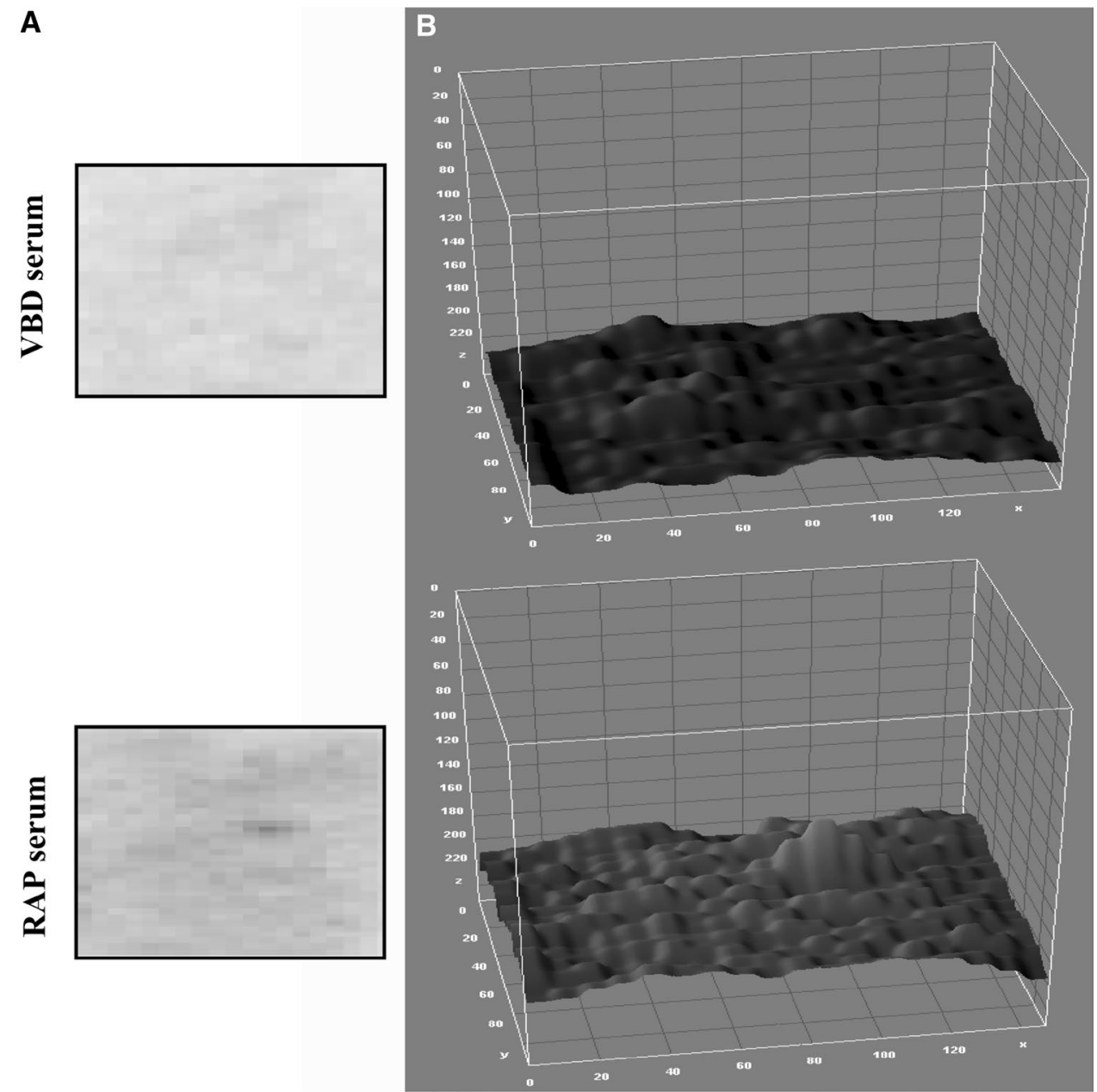

system has been observed (Konieczna et al. 2012). A hallmark of RA is production of a broad spectrum of antibodies, including autoantibodies such as rheumatoid factor (RF), antikeratin antibody (AKA), antiperinuclear factor (APF), and anti-RA33 (Aho et al. 1994). Serological tests are still a major tool for diagnosis and investigation of the immune response of patients with systemic rheumatic diseases: RA, lupus erythematosus, systemic sclerosis, primary Sjögren's syndrome and inflammatory myopathy (Op De Beeck et al. 2011; Schur 2005). A number of different methods may be applied for this purpose: techniques based on indirect observation of immune complexes, such as nephelometry (Schur 2005), immunodiffusion and flow cytometry (Salamunić 2010; Aho et al. 1994), or techniques that require conjugated secondary anti-human antibodies for detection of human antibodies bound to the antigen, such as ELISA or dot-blot (Konieczna et al. 2012; Schur 2005).

The mechanism for development of RA is not fully understood, but probably involves infectious agents. Wilson et al. identified sera antibodies against $P$. mirabilis urease in RA patients. Moreover, those antibodies cross-reacted with human collagen in joint cartilage, which resulted in joint damage (Wilson et al. 1995). In our previous study, we found a higher level of $H$. pylori antiurease antibodies in a cohort of 40 RA patients compared to $38 \mathrm{VBD}$, which also recognized urease flap fragments from $P$. mirabilis and other organisms such as $H$. pylori, Staphylococcus sp. and even C. ensiformis (Konieczna et al. 2012). Herein, we compared the previously applied dot-blot method, based on colorimetric detection of reaction products formed in the presence of antihuman HRPmodified antibodies, with a variant based on detection of fluorescence caused by binding to fluorescein-modified antibodies.

Both methods have advantages and disadvantages, and both are easily performed. In classic dot-blot, however, preparation of the membrane pieces with immobilized synthetic peptides is much simpler. Fluorescent dot-blot is more time-consuming because exactly the same size of each piece of cellulose membrane is essential to obtain reproducible results. 
Table 1 Peptide sub-libraries (1-19 in rows) based on the 19-amino acid sequence of H. pylori urease flap region. $\mathrm{X}=$ one of 19 amino acid residues $\mathrm{a}-\mathrm{w}$

\begin{tabular}{|c|c|c|c|c|c|c|c|c|c|c|c|c|c|c|c|c|c|c|c|c|}
\hline & \multicolumn{19}{|c|}{ Sub-libraries based on the BK-61B sequence } \\
\hline & & $\mathbf{C}^{\mathbf{1}}$ & $\mathbf{H}$ & $\mathbf{H}^{3}$ & $\mathbf{L}^{4}$ & $D^{5}$ & $K^{6}$ & $\mathbf{S}^{7}$ & $\mathbf{I}^{8}$ & $\mathbf{K}^{9}$ & $\mathbf{E}^{10}$ & $D^{11}$ & $\mathbf{V}^{12}$ & $Q^{13}$ & $F^{14}$ & $A^{15}$ & $D^{16}$ & $S^{17}$ & $\mathbf{R}^{18}$ & $\mathbf{I}^{19}$ \\
\hline & 1 & $\mathbf{X}$ & $\mathrm{H}$ & $\mathrm{H}$ & $\mathrm{L}$ & $\mathrm{D}$ & $\mathrm{K}$ & $\mathrm{S}$ & I & $\mathrm{K}$ & $\mathrm{E}$ & $\mathrm{D}$ & $\mathrm{V}$ & $\mathrm{Q}$ & $\mathrm{F}$ & $\mathrm{A}$ & $\mathrm{D}$ & $\mathrm{S}$ & $\mathrm{R}$ & I \\
\hline & 2 & $\mathrm{C}$ & $\mathbf{X}$ & $\mathrm{H}$ & $\mathrm{L}$ & D & K & $\mathrm{S}$ & I & $\mathrm{K}$ & $\mathrm{E}$ & $\mathrm{D}$ & V & $\mathrm{Q}$ & $\mathrm{F}$ & A & D & $\mathrm{S}$ & $\mathrm{R}$ & I \\
\hline & 3 & $\mathrm{C}$ & $\mathrm{H}$ & $\mathbf{X}$ & $\mathrm{L}$ & D & K & $\mathrm{S}$ & I & $\mathrm{K}$ & $\mathrm{E}$ & D & V & $\mathrm{Q}$ & $\mathrm{F}$ & A & D & S & $\mathrm{R}$ & I \\
\hline & 4 & $\mathrm{C}$ & $\mathrm{H}$ & $\mathrm{H}$ & $\mathbf{X}$ & D & $\mathrm{K}$ & $\mathrm{S}$ & I & $\mathrm{K}$ & $\mathrm{E}$ & $\mathrm{D}$ & $\mathrm{V}$ & $\mathrm{Q}$ & $\mathrm{F}$ & A & $\mathrm{D}$ & $S$ & $\mathrm{R}$ & I \\
\hline & 5 & $\mathrm{C}$ & $\mathrm{H}$ & $\mathrm{H}$ & $\mathrm{L}$ & $X$ & $\mathrm{~K}$ & $\mathrm{~S}$ & I & $\mathrm{K}$ & $\mathrm{E}$ & $\mathrm{D}$ & V & $\mathrm{Q}$ & $\mathrm{F}$ & A & D & $\mathrm{S}$ & $\mathrm{R}$ & I \\
\hline 6 & 6 & $\mathrm{C}$ & $\mathrm{H}$ & $\mathrm{H}$ & $\mathrm{L}$ & $D$ & $\mathbf{X}$ & $\mathrm{S}$ & I & $\mathrm{K}$ & $\mathrm{E}$ & $\mathrm{D}$ & V & $\mathrm{Q}$ & $\mathrm{F}$ & A & D & $\mathrm{S}$ & $\mathrm{R}$ & I \\
\hline :의 & 7 & $\mathrm{C}$ & $\mathrm{H}$ & $\mathrm{H}$ & $\mathrm{L}$ & D & K & X & I & $\mathrm{K}$ & $\mathrm{E}$ & $\mathrm{D}$ & $\mathrm{V}$ & $\mathrm{Q}$ & $\mathrm{F}$ & A & D & S & $\mathrm{R}$ & I \\
\hline 8 & 8 & $\mathrm{C}$ & $\mathrm{H}$ & $\mathrm{H}$ & $\mathrm{L}$ & D & K & $\mathrm{S}$ & $\mathbf{X}$ & $\mathrm{K}$ & $\mathrm{E}$ & $\mathrm{D}$ & V & $\mathrm{Q}$ & $\mathrm{F}$ & A & D & $\mathrm{S}$ & $\mathrm{R}$ & I \\
\hline & 9 & $\mathrm{C}$ & $\mathrm{H}$ & $\mathrm{H}$ & $\mathrm{L}$ & $D$ & $\mathrm{~K}$ & $\mathrm{~S}$ & I & $\mathbf{X}$ & $\mathrm{E}$ & $\mathrm{D}$ & $\mathrm{V}$ & $\mathrm{Q}$ & $\mathrm{F}$ & A & D & $S$ & $\mathrm{R}$ & I \\
\hline$\dot{\bar{D}} \mathbf{1}$ & 10 & $\mathrm{C}$ & $\mathrm{H}$ & $\mathrm{H}$ & $\mathrm{L}$ & D & $\mathrm{K}$ & $\mathrm{S}$ & I & $\mathrm{K}$ & $\mathbf{x}$ & $\mathrm{D}$ & $\mathrm{V}$ & $\mathrm{Q}$ & $\mathrm{F}$ & A & $\mathrm{D}$ & $S$ & $\mathrm{R}$ & I \\
\hline 1 & 11 & $\mathrm{C}$ & $\mathrm{H}$ & $\mathrm{H}$ & $\mathrm{L}$ & D & $\mathrm{K}$ & $\mathrm{S}$ & I & $\mathrm{K}$ & $\mathrm{E}$ & $\mathbf{X}$ & V & $\mathrm{Q}$ & $\mathrm{F}$ & A & D & $\mathrm{S}$ & $\mathrm{R}$ & I \\
\hline 1 & 12 & $\mathrm{C}$ & $\mathrm{H}$ & $\mathrm{H}$ & $\mathrm{L}$ & D & $\mathrm{K}$ & $\mathrm{S}$ & I & $\mathrm{K}$ & $\mathrm{E}$ & $\mathrm{D}$ & $\mathbf{X}$ & $\mathrm{Q}$ & $\mathrm{F}$ & A & $\mathrm{D}$ & $\mathrm{S}$ & $\mathrm{R}$ & I \\
\hline & 13 & $\mathrm{C}$ & $\mathrm{H}$ & $\mathrm{H}$ & $\mathrm{L}$ & $D$ & $\mathrm{~K}$ & $\mathrm{~S}$ & I & $\mathrm{K}$ & $\mathrm{E}$ & $\mathrm{D}$ & V & $\mathbf{X}$ & $\mathrm{F}$ & A & $\mathrm{D}$ & $\mathrm{S}$ & $\mathrm{R}$ & I \\
\hline & 14 & $\mathrm{C}$ & $\mathrm{H}$ & $\mathrm{H}$ & $\mathrm{L}$ & D & $\mathrm{K}$ & $\mathrm{S}$ & I & $\mathrm{K}$ & $\mathrm{E}$ & $\mathrm{D}$ & V & $\mathrm{Q}$ & $\mathbf{X}$ & A & D & $S$ & $\mathrm{R}$ & I \\
\hline & 15 & $\mathrm{C}$ & $\mathrm{H}$ & $\mathrm{H}$ & $\mathrm{L}$ & D & $\mathrm{K}$ & $\mathrm{S}$ & I & $\mathrm{K}$ & $\mathrm{E}$ & $\mathrm{D}$ & V & $\mathrm{Q}$ & $\mathrm{F}$ & $\mathbf{X}$ & $\mathrm{D}$ & $\mathrm{S}$ & $\mathrm{R}$ & I \\
\hline & 16 & $\mathrm{C}$ & $\mathrm{H}$ & $\mathrm{H}$ & $\mathrm{L}$ & $D$ & $\mathrm{~K}$ & $\mathrm{~S}$ & I & $\mathrm{K}$ & $\mathrm{E}$ & $\mathrm{D}$ & V & $\mathrm{Q}$ & $\mathrm{F}$ & A & $\mathbf{X}$ & $\mathrm{S}$ & $\mathrm{R}$ & I \\
\hline & 17 & $\mathrm{C}$ & $\mathrm{H}$ & $\mathrm{H}$ & $\mathrm{L}$ & D & $\mathrm{K}$ & $\mathrm{S}$ & I & $\mathrm{K}$ & $\mathrm{E}$ & $\mathrm{D}$ & V & $\mathrm{Q}$ & $\mathrm{F}$ & A & $\mathrm{D}$ & $X$ & $\mathrm{R}$ & I \\
\hline & 18 & C & $\mathrm{H}$ & $\mathrm{H}$ & $\mathrm{L}$ & D & $\mathrm{K}$ & $\mathrm{S}$ & I & $\mathrm{K}$ & $\mathrm{E}$ & $\mathrm{D}$ & V & $\mathrm{Q}$ & $\mathrm{F}$ & A & D & $\mathrm{S}$ & $X$ & I \\
\hline & 19 & $\mathrm{C}$ & $\mathrm{H}$ & $\mathrm{H}$ & $\mathrm{L}$ & $D$ & $\mathrm{~K}$ & $\mathrm{~S}$ & I & $\mathrm{K}$ & $\mathrm{E}$ & $\mathrm{D}$ & $\mathrm{V}$ & $\mathrm{Q}$ & $\mathrm{F}$ & A & D & $\mathrm{S}$ & $\mathrm{R}$ & $\mathbf{X}$ \\
\hline
\end{tabular}

During chemical synthesis, peptides were immobilized on both sides of the cellulose membranes. This was noticeable in the serologic investigations, but reaction was stronger on one side of the membranes. Moreover, heterogeneity of serum reaction on the membrane surface was observed. It is likely that the antibodies have better access to peptides on one side of the membrane during incubation with serum in the microtiter plate. Heterogeneity of reaction may result from diverse binding of secondary anti-human antibodies or local accumulation of precipitated product arising from HRP action.

The studies with synthetic peptides corresponding to the flap fragment of urease from different organisms revealed that fluorescence measurement was significantly less dependent on dilution than the colorimetric method. Moreover, the fluorescence response for $H$. pylori urease fragment BK65-B was stronger than the colorimetric response, although the strengths of reaction with VBD and RA patient serum were less diverse. Data obtained for peptides corresponding to urease flap fragments from other organisms using the classic dot-blot technique showed higher differentiation of tested sera (RAP versus VBD). Nevertheless, differences were also visible with fluorescence detection, but only at higher sera dilutions. This results in lower use of analyzed sera, which may sometimes be very valuable. On the other hand, the price of secondary anti-human antibodies conjugated with fluorescein is higher than antibodies conjugated with HRP. Notwithstanding, the process to obtain results is much shorter in fluorescent dot-blot. The classic method requires time-consuming processing of the scanned image of membranes after reaction, but the obtained results are more reproducible if the size of the scanned surface is sufficiently large to average local non-homogeneity. It should be mentioned that in colorimetric detection of HRP reaction products, less than $5 \%$ of the results were rejected (data not shown). This is consistent with earlier observations that the fluorescence technique is sensitive, but standardization is complicated and crucial for reproducibility (Salamunić 2010).

The fluorescent dot-blot method was used to conduct an amino acid scan of $H$. pylori urease flap sequence fragment (BK-65B). All peptides were immobilized on cellulose membranes. The library contained 19 sub-libraries and in each sub-library, immobilized peptides were prepared on 19 membranes. On each membrane one amino acid residue at a defined position of the native BK65-B peptide was systematically replaced by each of the 19 proteinogenic amino acids. All 361 membranes with immobilized peptides, each differing from the others by one amino acid residue at one defined position, were prepared by a solid phase peptide 
Table 2 Component structures of sub-libraries 1-19

\begin{tabular}{|c|c|c|c|c|c|c|c|c|c|c|c|c|c|c|c|c|c|c|c|}
\hline \multirow{2}{*}{ sub-library } & \multicolumn{19}{|c|}{ Components of sub-libraries, structure of X } \\
\hline & $\mathbf{a}$ & $\mathbf{b}$ & c & d & e & $\mathbf{f}$ & g & $\mathbf{h}$ & $\mathbf{i}$ & $\mathbf{j}$ & $\mathbf{k}$ & 1 & $\mathbf{m}$ & $\mathbf{n}$ & $\mathbf{0}$ & $\mathbf{p}$ & $\mathbf{q}$ & $\mathbf{u}$ & $r$ \\
\hline $\begin{array}{c}1 \\
\text { HHLDKSIKED }\end{array}$ & $\mathrm{A}$ & $\mathrm{V}$ & $\mathrm{L}$ & I & $\mathrm{F}$ & $\mathrm{Y}$ & $\mathrm{T}$ & $\mathrm{S}$ & M & $\mathrm{D}$ & $\mathrm{E}$ & $\mathrm{N}$ & Q & $\mathrm{K}$ & $\mathrm{H}$ & $\mathrm{R}$ & $\mathrm{W}$ & $\mathrm{P}$ & $\mathrm{G}$ \\
\hline $\begin{array}{r}\mathbf{2} \\
\text { HLDKSIKED }\end{array}$ & $\mathrm{A}$ & $\mathrm{V}$ & $\mathrm{L}$ & I & $\mathrm{F}$ & $\mathrm{Y}$ & $\mathrm{T}$ & $\mathrm{S}$ & $\mathrm{M}$ & $\mathrm{D}$ & $\mathrm{E}$ & $\mathrm{N}$ & $\mathrm{Q}$ & $\mathrm{K}$ & $\mathrm{C}$ & $\mathrm{R}$ & $\mathrm{W}$ & $\mathrm{P}$ & $\mathrm{G}$ \\
\hline $\begin{array}{r}\mathbf{3} \\
\mathbf{X L D K S I K E D} \\
\end{array}$ & $\mathrm{A}$ & $\mathrm{V}$ & $\mathrm{L}$ & $\mathrm{I}$ & $\mathrm{F}$ & $\mathrm{Y}$ & $\mathrm{T}$ & $\mathrm{S}$ & $\mathrm{M}$ & $\mathrm{D}$ & $\mathrm{E}$ & $\mathrm{N}$ & Q & $\mathrm{K}$ & $\mathrm{C}$ & $\mathrm{R}$ & $\mathrm{W}$ & $\mathrm{P}$ & $\mathrm{G}$ \\
\hline $\begin{array}{r}\mathbf{4} \\
\text { HHXDKSIKED } \\
\end{array}$ & $\mathrm{A}$ & $\mathrm{V}$ & $\mathrm{C}$ & I & $\mathrm{F}$ & $\mathrm{Y}$ & $\mathrm{T}$ & $\mathrm{S}$ & $\mathrm{M}$ & $\mathrm{D}$ & $\mathrm{E}$ & $\mathrm{N}$ & Q & $\mathrm{K}$ & $\mathrm{H}$ & $\mathrm{R}$ & $\mathrm{W}$ & $\mathrm{P}$ & $\mathrm{G}$ \\
\hline $\begin{array}{r}\mathbf{5} \\
\text { HLXKSIKED }\end{array}$ & $\mathrm{A}$ & $\mathrm{V}$ & $\mathrm{L}$ & I & $\mathrm{F}$ & $\mathrm{Y}$ & $\mathrm{T}$ & $\mathrm{S}$ & $\mathrm{M}$ & $\mathrm{C}$ & $\mathrm{E}$ & $\mathrm{N}$ & Q & $\mathrm{K}$ & $\mathrm{H}$ & $\mathrm{R}$ & $\mathrm{W}$ & $\mathrm{P}$ & G \\
\hline $\begin{array}{r}\mathbf{6} \\
\text { HHLDXSIKEI }\end{array}$ & $\mathrm{A}$ & $\mathrm{V}$ & $\mathrm{L}$ & I & $\mathrm{F}$ & $\mathrm{Y}$ & $\mathrm{T}$ & $\mathrm{S}$ & $\mathrm{M}$ & $\mathrm{D}$ & $\mathrm{E}$ & $\mathrm{N}$ & Q & $\mathrm{C}$ & $\mathrm{H}$ & $\mathrm{R}$ & $\mathrm{W}$ & $\mathrm{P}$ & $\mathrm{G}$ \\
\hline $\begin{array}{c}7 \\
\text { HLDKXIKED }\end{array}$ & $\mathrm{A}$ & $\mathrm{V}$ & $\mathrm{L}$ & $\mathrm{I}$ & $\mathrm{F}$ & $\mathrm{Y}$ & $\mathrm{T}$ & $\mathrm{C}$ & $\mathrm{M}$ & $\mathrm{D}$ & $\mathrm{E}$ & $\mathrm{N}$ & Q & $\mathrm{K}$ & $\mathrm{H}$ & $\mathrm{R}$ & $\mathrm{W}$ & $\mathrm{P}$ & $\mathrm{G}$ \\
\hline $\begin{array}{r}\mathbf{8} \\
\mathrm{KE} \\
\end{array}$ & $\mathrm{A}$ & $\mathrm{V}$ & $\mathrm{L}$ & $\mathrm{C}$ & $\mathrm{F}$ & $\mathrm{Y}$ & $\mathrm{T}$ & $\mathrm{S}$ & $\mathrm{M}$ & $\mathrm{D}$ & $\mathrm{E}$ & $\mathrm{N}$ & Q & $\mathrm{K}$ & $\mathrm{H}$ & $\mathrm{R}$ & $\mathrm{W}$ & $\mathrm{P}$ & $\mathrm{G}$ \\
\hline $\begin{array}{r}9 \\
\text { IHLDKSIXED }\end{array}$ & $\mathrm{A}$ & $\mathrm{V}$ & $\mathrm{L}$ & $\mathrm{I}$ & $\mathrm{F}$ & $\mathrm{Y}$ & $\mathrm{T}$ & $\mathrm{S}$ & $\mathrm{M}$ & $\mathrm{D}$ & $\mathrm{E}$ & $\mathrm{N}$ & Q & $\mathrm{C}$ & $\mathrm{H}$ & $\mathrm{R}$ & $\mathrm{W}$ & $\mathrm{P}$ & $\mathrm{G}$ \\
\hline $\begin{array}{r}10 \\
\text { HHLDKSIKXD }\end{array}$ & $\mathrm{A}$ & $\mathrm{V}$ & $\mathrm{L}$ & I & $\mathrm{F}$ & $\mathrm{Y}$ & $\mathrm{T}$ & $\mathrm{S}$ & $\mathrm{M}$ & $\mathrm{D}$ & $\mathrm{C}$ & $\mathrm{N}$ & Q & $\mathrm{K}$ & $\mathrm{H}$ & $\mathrm{R}$ & $\mathrm{W}$ & $\mathrm{P}$ & $\mathrm{G}$ \\
\hline $\begin{array}{r}11 \\
\text { HHLDKSIKEX }\end{array}$ & $\mathrm{A}$ & $\mathrm{V}$ & $\mathrm{L}$ & $\mathrm{I}$ & $\mathrm{F}$ & $\mathrm{Y}$ & $\mathrm{T}$ & $\mathrm{S}$ & $\mathrm{M}$ & $\mathrm{C}$ & $\mathrm{E}$ & $\mathrm{N}$ & Q & $\mathrm{K}$ & $\mathrm{H}$ & $\mathrm{R}$ & $\mathrm{W}$ & $\mathrm{P}$ & $\mathrm{G}$ \\
\hline 12 & $\mathrm{~A}$ & $\mathrm{C}$ & $\mathrm{L}$ & I & $\mathrm{F}$ & $\mathrm{Y}$ & $\mathrm{T}$ & $\mathrm{S}$ & $\mathrm{M}$ & $\mathrm{D}$ & $\mathrm{E}$ & $\mathrm{N}$ & Q & $\mathrm{K}$ & $\mathrm{H}$ & $\mathrm{R}$ & $\mathrm{W}$ & $\mathrm{P}$ & $\mathrm{G}$ \\
\hline 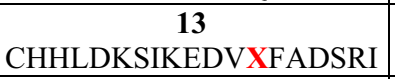 & $\mathrm{A}$ & $\mathrm{V}$ & $\mathrm{L}$ & $\mathrm{I}$ & $\mathrm{F}$ & $\mathrm{Y}$ & $\mathrm{T}$ & $\mathrm{S}$ & $\mathrm{M}$ & $\mathrm{D}$ & $\mathrm{E}$ & $\mathrm{N}$ & $\mathrm{C}$ & $\mathrm{K}$ & $\mathrm{H}$ & $\mathrm{R}$ & $\mathrm{W}$ & $\mathrm{P}$ & $\mathrm{G}$ \\
\hline $\begin{array}{r}14 \\
\text { CHHLDKSIKED }\end{array}$ & $\mathrm{A}$ & $\mathrm{V}$ & $\mathrm{L}$ & I & $\mathrm{C}$ & $\mathrm{Y}$ & $\mathrm{T}$ & $\mathrm{S}$ & $\mathrm{M}$ & $\mathrm{D}$ & $\mathrm{E}$ & $\mathrm{N}$ & Q & $\mathrm{K}$ & $\mathrm{H}$ & $\mathrm{R}$ & $\mathrm{W}$ & $\mathrm{P}$ & $\mathrm{G}$ \\
\hline $\begin{array}{r}15 \\
\text { CHHLDKSIKED } \\
\end{array}$ & $\mathrm{C}$ & $\mathrm{V}$ & $\mathrm{L}$ & I & $\mathrm{F}$ & $\mathrm{Y}$ & $\mathrm{T}$ & $\mathrm{S}$ & $\mathrm{M}$ & $\mathrm{D}$ & $\mathrm{E}$ & $\mathrm{N}$ & Q & $\mathrm{K}$ & $\mathrm{H}$ & $\mathrm{R}$ & $\mathrm{W}$ & $\mathrm{P}$ & $\mathrm{G}$ \\
\hline $\begin{array}{c}\mathbf{1 6} \\
\text { CHHLDKSIKEDVQFAXSRI }\end{array}$ & $\mathrm{A}$ & $\mathrm{V}$ & $\mathrm{L}$ & I & $\mathrm{F}$ & $\mathrm{Y}$ & $\mathrm{T}$ & $\mathrm{S}$ & $\mathrm{M}$ & $\mathrm{C}$ & $\mathrm{E}$ & $\mathrm{N}$ & Q & $\mathrm{K}$ & $\mathrm{H}$ & $\mathrm{R}$ & $\mathrm{W}$ & $\mathrm{P}$ & $\mathrm{G}$ \\
\hline $\begin{array}{c}17 \\
\text { CHHLDKSIKED }\end{array}$ & $\mathrm{A}$ & $\mathrm{V}$ & $\mathrm{L}$ & $\mathrm{I}$ & $\mathrm{F}$ & $\mathrm{Y}$ & $\mathrm{T}$ & $\mathrm{C}$ & $\mathrm{M}$ & $\mathrm{D}$ & $\mathrm{E}$ & $\mathrm{N}$ & Q & $\mathrm{K}$ & $\mathrm{H}$ & $\mathrm{R}$ & $\mathrm{W}$ & $\mathrm{P}$ & $\mathrm{G}$ \\
\hline 18 & $\mathrm{~A}$ & $\mathrm{~V}$ & $\mathrm{~L}$ & I & $\mathrm{F}$ & $\mathrm{Y}$ & $\mathrm{T}$ & $\mathrm{S}$ & $\mathrm{M}$ & $\mathrm{D}$ & $\mathrm{E}$ & $\mathrm{N}$ & Q & $\mathrm{K}$ & $\mathrm{H}$ & $\mathrm{C}$ & $\mathrm{W}$ & $\mathrm{P}$ & $\mathrm{G}$ \\
\hline $\begin{array}{r}19 \\
\text { HHLDKSIKED }\end{array}$ & $\mathrm{A}$ & $\mathrm{V}$ & $\mathrm{L}$ & $\mathrm{C}$ & $\mathrm{F}$ & $\mathrm{Y}$ & $\mathrm{T}$ & $\mathrm{S}$ & $\mathrm{M}$ & $\mathrm{D}$ & $\mathrm{E}$ & $\mathrm{N}$ & Q & $\mathrm{K}$ & $\mathrm{H}$ & $\mathrm{R}$ & $\mathrm{W}$ & $\mathrm{P}$ & $G$ \\
\hline
\end{tabular}

synthesis procedure using 4-(4,6-dimethoxy-1,3,5-triazin2-yl)-4-methylmorpholinium toluene-4-sulfonate (DMT/ $\mathrm{NMM} / \mathrm{TsO}^{-}$) as a coupling reagent (Kolesinska et al. 2015). HPLC and MS analysis of 30 randomly selected peptides cleaved from the cellulose matrix confirmed high efficiency of DMT/NMM/TsO ${ }^{-}$, proposed as a new standard condensing reagent for preparation of peptide libraries according to the SPOT procedure (Fraczyk et.al. 2018). In all cases no products with a deletion of amino acids were observed, and the purities of the isolated crude peptides were very high.

The successful preparation of the library of $361 \mathrm{H}$. pylori urease fragment BK-65B analogues enabled elucidation of the diverse responses of individual patients towards variation of the antigen structure. The reactions of one randomly selected RA patient serum and one randomly selected VBD serum with all members of the peptide library were substantially weaker than with the native BK-65B sequence. The most conservative fragment was $\mathrm{L}^{4} \mathrm{D}^{5} \mathrm{~K}^{6} \mathrm{~S}^{7} \mathrm{I}^{8} \mathrm{~K}^{9}$ (sublibraries 4-9). In most cases, any modification of these residues prevented interaction or gave weak interactions with both sera samples. This is very interesting because Proteus, Staphylococcus and C. ensiformis ureases have different amino acid residues within this fragment. The other conservative fragments were $\mathrm{C}^{1} \mathrm{H}^{2}$ (sub-libraries 1-2), $\mathrm{E}^{10} \mathrm{D}^{11} \mathrm{~V}^{12}$ (sub-libraries $10-12$ ) and $\mathrm{A}^{15}$ (sub-library 15 ). 
Table 3 HR-MS analysis of randomly selected oligopeptides from sub-libraries 2-19

\begin{tabular}{|c|c|c|}
\hline \multicolumn{2}{|c|}{ Peptide in sub-library } & \multirow[t]{2}{*}{ HR-MS result } \\
\hline No. & Sequence & \\
\hline $2 b$ & CVHLDKSIKEDVQFADSRI & $2204.1267\left([\mathrm{M}+\mathrm{H}]^{+}\right.$; calc. $\left.\mathrm{C}_{95} \mathrm{H}_{156} \mathrm{~N}_{27} \mathrm{O}_{31} \mathrm{~S}_{3}{ }^{+} 2204.1137\right)$ \\
\hline 21 & CNHLDKSIKEDVQFADSRI & $2219.0981\left([\mathrm{M}+\mathrm{H}]^{+}\right.$; calc. $\left.\mathrm{C}_{94} \mathrm{H}_{153} \mathrm{~N}_{28} \mathrm{O}_{32} \mathrm{~S}^{+} 2219.0882\right)$ \\
\hline $3 \mathrm{~d}$ & CHILDKSIKEDVQFADSRI & $2218.1327\left([\mathrm{M}+\mathrm{H}]^{+}\right.$; calc. $\left.\mathrm{C}_{96} \mathrm{H}_{158} \mathrm{~N}_{27} \mathrm{O}_{31} \mathrm{~S}^{+} 2218.1293\right)$ \\
\hline $3 n$ & CHKLDKSIKEDVQFADSRI & $2233.1339\left([\mathrm{M}+\mathrm{H}]^{+}\right.$; calc. $\left.\mathrm{C}_{96} \mathrm{H}_{159} \mathrm{~N}_{28} \mathrm{O}_{31} \mathrm{~S}^{+} 2233.1402\right)$ \\
\hline $4^{\mathrm{a}}$ & CHHADKSIKEDVQFADSRI & $2200.0606\left([\mathrm{M}+\mathrm{H}]^{+}\right.$; calc. $\left.\mathrm{C}_{93} \mathrm{H}_{148} \mathrm{~N}_{29} \mathrm{O}_{31} \mathrm{~S}^{+} 2200.0572\right)$ \\
\hline $4 u$ & CHHPDKSIKEDVQFADSRI & 2226.0762([M+H] $]^{+}$; calc. $\left.\mathrm{C}_{95} \mathrm{H}_{150} \mathrm{~N}_{29} \mathrm{O}_{31} \mathrm{~S}^{+} 2226.0729\right)$ \\
\hline $5 f$ & CHHLYKSIKEDVQFADSRI & $2290.1439\left([\mathrm{M}+\mathrm{H}]^{+}\right.$; calc. $\left.\mathrm{C}_{101} \mathrm{H}_{158} \mathrm{~N}_{29} \mathrm{O}_{30} \mathrm{~S}^{+} 2290.1405\right)$ \\
\hline $6 e$ & CHHLDFSIKEDVQFADSRI & $2261.0746\left([\mathrm{M}+\mathrm{H}]^{+}\right.$; calc. $\left.\mathrm{C}_{99} \mathrm{H}_{151} \mathrm{~N}_{28} \mathrm{O}_{31} \mathrm{~S}+2261.0776\right)$ \\
\hline $6 \mathrm{~m}$ & CHHLDQSIKEDVQFADSRI & $2242.0602\left([\mathrm{M}+\mathrm{H}]^{+}\right.$; calc. $\left.\mathrm{C}_{95} \mathrm{H}_{150} \mathrm{~N}_{29} \mathrm{O}_{32} \mathrm{~S}^{+} 2242.0678\right)$ \\
\hline $7 \mathrm{c}$ & CHHLDKLIKEDVQFADSRI & $2268.1625\left([\mathrm{M}+\mathrm{H}]^{+}\right.$; calc. $\left.\mathrm{C}_{99} \mathrm{H}_{160} \mathrm{~N}_{29} \mathrm{O}_{30} \mathrm{~S}^{+} 2268.1562\right)$ \\
\hline $7 \mathrm{j}$ & CHHLDKDIKEDVQFADSRI & $2270.0982\left([\mathrm{M}+\mathrm{H}]^{+}\right.$; calc. $\left.\mathrm{C}_{97} \mathrm{H}_{154} \mathrm{~N}_{29} \mathrm{O}_{32} \mathrm{~S}^{+} 2270.0991\right)$ \\
\hline $8 \mathrm{~g}$ & CHHLDKSTKEDVQFADSRI & $2230.0602\left([\mathrm{M}+\mathrm{H}]^{+}\right.$; calc. $\left.\mathrm{C}_{94} \mathrm{H}_{150} \mathrm{~N}_{29} \mathrm{O}_{32} \mathrm{~S}^{+} 2230.0678\right)$ \\
\hline $9 \mathrm{c}$ & CHHLDKSILEDVQFADSRI & $2227.0995\left([\mathrm{M}+\mathrm{H}]^{+}\right.$; calc. $\left.\mathrm{C}_{96} \mathrm{H}_{153} \mathrm{~N}_{28} \mathrm{O}_{31} \mathrm{~S}^{+} 2227.0933\right)$ \\
\hline $9 \mathrm{k}$ & CHHLDKSIEEDVQFADSRI & $2243.0581\left([\mathrm{M}+\mathrm{H}]^{+}\right.$; calc. $\left.\mathrm{C}_{95} \mathrm{H}_{149} \mathrm{~N}_{28} \mathrm{O}_{33} \mathrm{~S}^{+} 2243.0518\right)$ \\
\hline $10 \mathrm{~m}$ & CHHLDKSIKQDVQFADSRI & $2241.1210\left([\mathrm{M}+\mathrm{H}]^{+}\right.$; calc. $\left.\mathrm{C}_{96} \mathrm{H}_{155} \mathrm{~N}_{30} \mathrm{O}_{30} \mathrm{~S}^{+} 2241.1201\right)$ \\
\hline $10 \mathrm{q}$ & CHHLDKSIKWDVQFADSRI & $2299.1379\left([\mathrm{M}+\mathrm{H}]^{+}\right.$; calc. $\left.\mathrm{C}_{102} \mathrm{H}_{157} \mathrm{~N}_{30} \mathrm{O}_{29} \mathrm{~S}^{+} 2299.1409\right)$ \\
\hline $11 \mathrm{~m}$ & CHHLDKSIKEQVQFADSRI & $2255.1391\left([\mathrm{M}+\mathrm{H}]^{+}\right.$; calc. $\left.\mathrm{C}_{97} \mathrm{H}_{157} \mathrm{~N}_{30} \mathrm{O}_{30} \mathrm{~S}^{+} 2255.1358\right)$ \\
\hline $12 \mathrm{e}$ & CHHLDKSIKEDFQFADSRI & $2290.0966\left([\mathrm{M}+\mathrm{H}]^{+}\right.$; calc. $\left.\mathrm{C}_{100} \mathrm{H}_{154} \mathrm{~N}_{29} \mathrm{O}_{31} \mathrm{~S}^{+} 2290.1042\right)$ \\
\hline 120 & CHHLDKSIKEDHQFADSRI & $2280.0871\left([\mathrm{M}+\mathrm{H}]^{+}\right.$; calc. $\left.\mathrm{C}_{97} \mathrm{H}_{152} \mathrm{~N}_{31} \mathrm{O}_{31} \mathrm{~S}^{+} 2280.0947\right)$ \\
\hline $13 \mathrm{a}$ & CHHLDKSIKEDVAFADSRI & $2185.0836\left([\mathrm{M}+\mathrm{H}]^{+}\right.$; calc. $\left.\mathrm{C}_{94} \mathrm{H}_{151} \mathrm{~N}_{28} \mathrm{O}_{30} \mathrm{~S}^{+} 2185.0827\right)$ \\
\hline $13 \mathrm{w}$ & CHHLDKSIKEDVGFADSRI & $2171.0641\left([\mathrm{M}+\mathrm{H}]^{+}\right.$; calc. $\left.\mathrm{C}_{93} \mathrm{H}_{149} \mathrm{~N}_{28} \mathrm{O}_{30} \mathrm{~S}^{+} 2171.0670\right)$ \\
\hline $14 \mathrm{~h}$ & CHHLDKSIKEDVQSADSRI & $2181.0614\left([\mathrm{M}+\mathrm{H}]^{+}\right.$; calc. $\left.\mathrm{C}_{90} \mathrm{H}_{150} \mathrm{~N}_{29} \mathrm{O}_{32} \mathrm{~S}^{+} 2181.0644\right)$ \\
\hline $15 f$ & CHHLDKSIKEDVQFYDSRI & $2334.1366\left([\mathrm{M}+\mathrm{H}]^{+}\right.$; calc. $\mathrm{C}_{102} \mathrm{H}_{158} \mathrm{~N}_{29} \mathrm{O}_{32} \mathrm{~S}^{+}$2334.1304) \\
\hline $15 \mathrm{j}$ & CHHLDKSIKEDVQFDDSRI & $2314.0898\left([\mathrm{M}+\mathrm{H}]^{+}\right.$; calc. $\mathrm{C}_{98} \mathrm{H}_{154} \mathrm{~N}_{29} \mathrm{O}_{34} \mathrm{~S}^{+}$2314.0889) \\
\hline $16 \mathrm{~h}$ & CHHLDKSIKEDVQFASSRI & $2214.1063\left([\mathrm{M}+\mathrm{H}]^{+}\right.$; calc. $\left.\mathrm{C}_{95} \mathrm{H}_{154} \mathrm{~N}_{29} \mathrm{O}_{30} \mathrm{~S}^{+} 2214.1092\right)$ \\
\hline $17 \mathrm{u}$ & CHHLDKSIKEDVQFADPRI & $2252.1219\left([\mathrm{M}+\mathrm{H}]^{+}\right.$; calc. $\left.\mathrm{C}_{98} \mathrm{H}_{156} \mathrm{~N}_{29} \mathrm{O}_{30} \mathrm{~S}^{+} 2252.1249\right)$ \\
\hline $18 \mathrm{n}$ & CHHLDKSIKEDVQFADSKI & $2214.0950\left([\mathrm{M}+\mathrm{H}]^{+}\right.$; calc. $\left.\mathrm{C}_{96} \mathrm{H}_{154} \mathrm{~N}_{27} \mathrm{O}_{31} \mathrm{~S}^{+} 2214.0980\right)$ \\
\hline $18 \mathrm{w}$ & CHHLDKSIKEDVQFADSGI & $2142.0215\left([\mathrm{M}+\mathrm{H}]^{+}\right.$; calc. $\left.\mathrm{C}_{92} \mathrm{H}_{145} \mathrm{~N}_{26} \mathrm{O}_{31} \mathrm{~S}^{+} 2142.0212\right)$ \\
\hline $19 \mathrm{a}$ & CHHLDKSIKEDVQFADSRA & $2200.0496\left([\mathrm{M}+\mathrm{H}]^{+}\right.$; calc. $\mathrm{C}_{93} \mathrm{H}_{148} \mathrm{~N}_{29} \mathrm{O}_{31} \mathrm{~S}^{+}$2200.0572) \\
\hline $19 \mathrm{e}$ & CHHLDKSIKEDVQFADSRF & $2276.0855\left([\mathrm{M}+\mathrm{H}]^{+}\right.$; calc. $\left.\mathrm{C}_{99} \mathrm{H}_{152} \mathrm{~N}_{29} \mathrm{O}_{31} \mathrm{~S}^{+} 2276.0885\right)$ \\
\hline
\end{tabular}

Modifications of amino acid residues in these fragments resulted in weak or only moderate reaction with sera. The residues most tolerant to modification were $D^{16} S^{17} R^{18} I^{19}$ (sub-libraries 16-19). In this fragment, as well as in $\mathrm{H}^{3}$ (sub-library 3) and $\mathrm{Q}^{13}$ (sub-library 13), the most substantial differences in reaction with VBD and RA patient sera were observed.

This analysis requires further study with a more representative number of sera samples.

In conclusion: by comparing the responses of the native BK-61B epitope sequence with responses of each library component with RAP patient and VBD sera it was anticipated that it would be possible to identify the tolerance of antibodies towards diverse amino acid composition in the epitope studied. The serological response is expected to be specific to and characteristic of the patient. This study has identified a pool of sequences promoting strong immunological reaction. Further analysis of the sequences necessary to generate a strong reaction with antibodies can provide rational data for prediction of molecular mimicry pathways for the particular patient. 


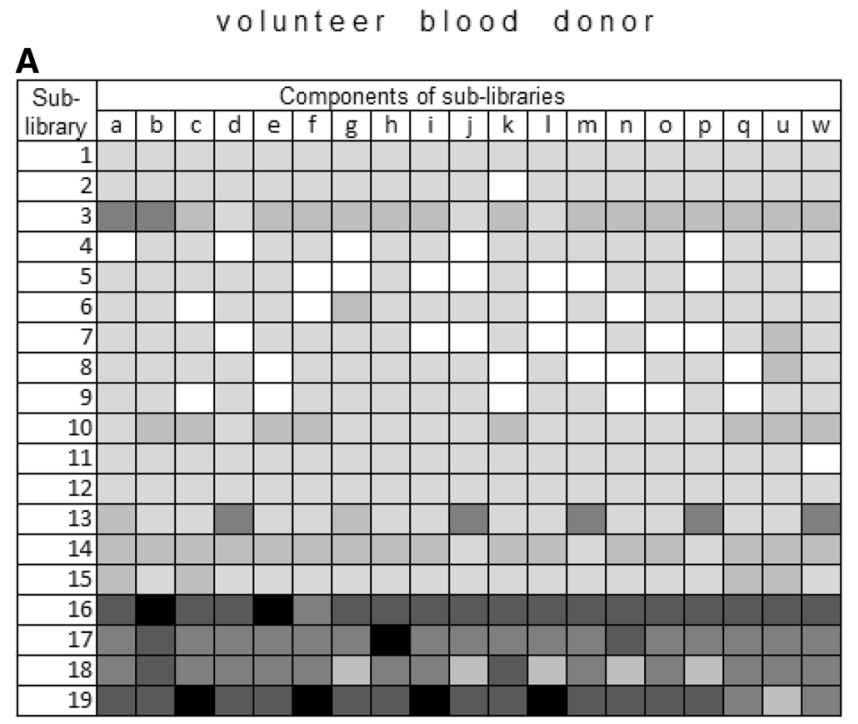

Fig. 4 Peptide library matrix reacted with VBD (a) and RA (b) patient serum, diluted 1:16,000, assayed by dot-blot fluorescence. Presented data are based on dot-blot cellulose developed using the fluorescence method. Black square-very strong reaction, fluorescence $>7000 \mathrm{U}$; slate colored-strong reaction, fluorescence 4001-

Table 4 Variance of population analysis for VBD and RAP sera in reactions with sub-libraries $1-19$

\begin{tabular}{lll}
\hline Peptide sub-library & Serum & \\
\cline { 2 - 3 } & VBD & RAP \\
\hline 1 & 712,617 & $\mathbf{1 , 0 0 9 , 4 0 0}$ \\
2 & $\mathbf{1 , 6 0 8 , 4 2 4}$ & 455,640 \\
3 & $\mathbf{5 , 2 7 5 , 5 0 0}$ & $4,286,003$ \\
4 & $\mathbf{1 , 9 8 8 , 5 8 8}$ & $1,576,132$ \\
5 & $1,254,874$ & $\mathbf{1 , 3 1 2 , 6 9 9}$ \\
6 & $1,362,551$ & $\mathbf{1 , 4 3 1 , 1 1 8}$ \\
7 & $2,730,001$ & $\mathbf{3 , 1 7 7 , 8 6 7}$ \\
8 & $2,599,163$ & $\mathbf{2 , 7 1 8 , 6 1 2}$ \\
9 & $1,292,660$ & $\mathbf{2 , 2 7 1 , 8 4 2}$ \\
10 & $\mathbf{5 , 5 2 2 , 4 0 8}$ & $1,834,379$ \\
11 & 440,005 & $\mathbf{1 , 1 2 0 , 5 3 5}$ \\
12 & $\mathbf{5 7 6 , 0 5 6}$ & 267,408 \\
13 & $3,028,002$ & $\mathbf{1 0 , 1 9 5 , 1 7 1}$ \\
14 & $2,470,370$ & $\mathbf{2 , 6 7 7 , 9 3 7}$ \\
15 & $\mathbf{2 , 0 3 7 , 5 2 5}$ & $1,036,655$ \\
16 & $\mathbf{6 , 5 0 1 , 3 7 0}$ & $3,571,244$ \\
17 & $3,341,253$ & $\mathbf{6 , 5 9 0 , 2 6 2}$ \\
18 & $5,968,446$ & $\mathbf{7 , 3 1 3 , 0 5 2}$ \\
19 & $10,380,446$ & $\mathbf{1 2 , 0 4 7 , 5 4 6}$ \\
\hline & & \\
\hline & &
\end{tabular}

Bold indicates greater diversity of antibody reactions with peptides from sub-library
B

RA patient

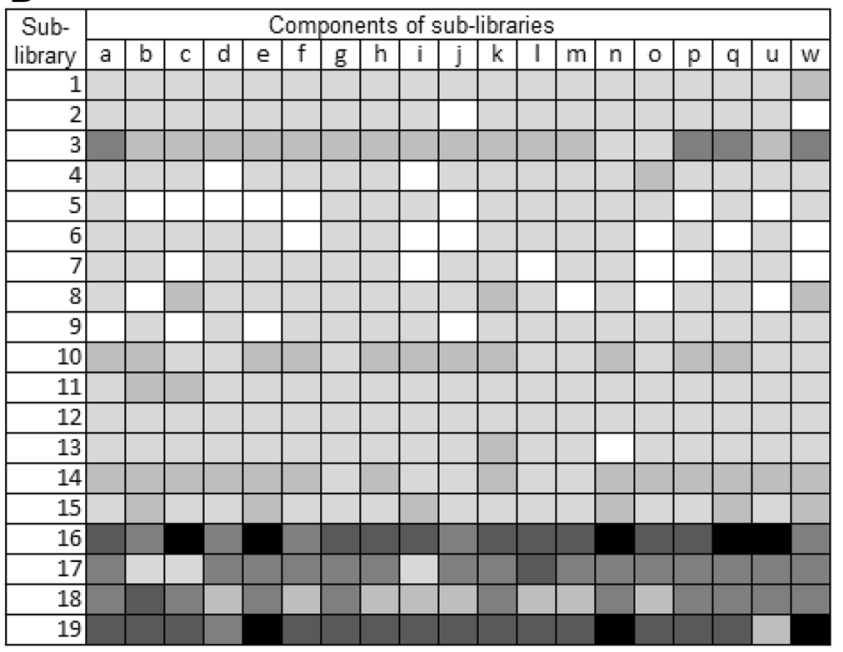

7000 units; grey-medium reaction, fluorescence 1501-4000 U; pale gray-weak reaction, fluorescence 101-1500 U; white-no serological reaction, fluorescence $<100 \mathrm{U}$. BK-65B epitope fluorescence $>20,000$ for VBD and RA patient

Acknowledgements The studies were supported by grants: UMO2011/03/D/NZ6/03316 from the National Science Center, Poland; "PRELUDIUM 8", from National Science Centre, Poland; UMO2014/15/N/NZ6/02505, 2012/05/N/ST5/01460 from the National Science Centre in Poland for I.R.; BS 2018 UJK for WK. The experiments were conducted on apparatus provided from grant POIG 2.2 for UJK. The authors are grateful to Wioletta Adamus-Białek, Mariusz Świercz and Dorota Derlatka for valuable suggestions and technical help with the experimental conditions.

Author Contributions All authors have read and approved the final article. WK, ZK, BK and IK participated in the conception and design of the study and the analysis and interpretation of data. BK, IK, JG-O, $\mathrm{KG}$ and $\mathrm{GC}$ carried out the chemical and biological experiments. BK, IK and GC drafted the manuscript. All authors have final approval of the version to be submitted.

\section{Compliance with Ethical Standards}

Conflict of interest The authors declare that they have no conflict of interest.

Ethical Approval Two sera samples used in the studies were left over from routine activity diagnostic tests and were designated for utilization. Ethical approval and informed consent were therefore not required. Patient sera were collected in diagnostic labs according to the Ethical Guidelines for Human Subjects.

Open Access This article is distributed under the terms of the Creative Commons Attribution 4.0 International License (http://creativeco mmons.org/licenses/by/4.0/), which permits unrestricted use, distribution, and reproduction in any medium, provided you give appropriate 
credit to the original author(s) and the source, provide a link to the Creative Commons license, and indicate if changes were made.

\section{References}

Agarwal SK (2011) An update for managed care professionals. J Manag Care Pharm 17(9):14-18

Aho K, Palusuo T, Kurki P (1994) Marker antibodies of rheumatoid arthritis: diagnostic and pathogenetic implications. Semin Arthr Rheum 23(6):379-387

Aletaha D, Neogi T, Silman AJ, Funovits J, Felson DT, Bingham CO, Birnbaum NS, Burmester GR, Bykerk VP, Cohen MD, Combe B, Costenbader KH, Dougados M, Emery P, Ferraccioli G, Hazes JMW, Hobbs K, Huizinga TWJ, Kavanaugh A, Kay J, Kvien TK, Laing T, Mease P, Menard HA, Moreland LW, Naden RL, Pincus T, Smolen JS, Stanislawska-Biernat E, Symmons D, Tak PP, Upchurch KS, Vencovský J, Wolfe F, Hawker G (2010) Rheumatoid arthritis classification criteria. Arthritis Rheum 62(9):2569-2581

Arabski M, Konieczna I, Sołowiej D, Rogoń A, Kaca W, Kolesińska B, Kamiński ZJ (2010) Are anti-H. pylori urease antibodies involved in atherosclerotic diseases? Clin Biochem 43:115-123

Bas S, Perneger TV, Seitz M, Tiercy JM, Roux-Lombard P and. Guerne PA (2002) Diagnostic tests for rheumatoid arthritis: comparison of anti-cyclic citrullinated peptide antibodies, anti-keratin antibodies and IgM rheumatoid factors. Rheumatology 41(7):809-814

Copse C, Fowler SJ (2002) Detection of proteins on Western Blots using chemifluorescence. The protein protocols handbook, Part III, Springer Protocols, pp 421-428. https://doi.org/10.1385/159259-169-8:421.

Corrao S, Calvo L, Licata G (2011) The new criteria for classification of rheumatoid arthritis: what we need to know for clinical practice. Eur J Intern Med 22(3):217-219

Fraczyk J, Walczak M, Kamiński JZ (2018) New Methodology for automated SPOT synthesis of peptides on cellulose using 1,3,5-triazine derivatives as linkers and as coupling reagents. J Pep Sci 2018;24:e3063. https://doi.org/10.1002/psc.3063

Gingrich JC, Davis DR, Nguyen Q (2000) Multiplex detection and quantitation of proteins on western blots using fluorescent probes. BioTechniques 29(3):636-642

Hirota K, Nagata K, Norose Y, Futagami S, Nakagawa Y, Senpuku H, Kobayashi M, Takahashi H (2001) Identification of an antigenic epitope in Helicobacter pylori urease that induces neutralizing antibody production. Infect Immun 69(11):6597-6603

Kamiński ZJ, Kolesińska B, Kolesińska J, Sabatino G, Chelli M, Rovero P, Błaszczyk M, Główka ML, Papini AM (2005) N-Triazinylammonium tetrafluoroborates. A new generation of efficient coupling reagents useful for peptide synthesis. J Am Chem Soc 127:16912-16920

Kamiński ZJ, Kolesińska B, Cierpucha M (2006) Sposób wytwarzania odczynnika kondensującego immobilizowanego na podłożu polimerowym. Patent ogłoszony 29 grudnia 2006 r, nr PL-192986, patent nr PL-192986

Kaminski ZJ, Relich I, Konieczna I, Kaca W, Kolesinska B (2018) Cross-reactivity of polyclonal antibodies against Canavalia ensiformis (Jack Bean) urease and Helicobacter pylori urease subunit A fragments. Chem Biodiversity. https://doi.org/10.1002/ cbdv. 201700444

Kolesińska B, Frączyk J, Papini AM, Kamiński ZJ (2007) Sulfonates of $\mathrm{N}$-triazinylammonium salts as highly efficient, inexpensive and environmentally friendly coupling reagents for peptide synthesis in solution. Chem Today (Chimica Oggi) 25:26-29

Konieczna I, Kwinkowski M, Kolesińska B, Kamiński Z, Frączyk J, Żarnowiec P, Kaca W (2012) Detection of antibodies against synthetic peptides mimicking ureases fragments in sera of rheumatoid arthritis patients. Protein Pept Lett 19(11):1149-1154

Kolesinska B, Rozniakowski KK, Fraczyk J, Relich I, Papini AM, Kaminski JZ (2015) The effect of counterion and tertiary amine on the efficiency of N-triazinylammonium sulfonates in solution and solid-phase peptide synthesis. Eur JOC. 2015:401-408

Mackenzie AR, Dawson J (2005) Could rheumatoid arthritis have an infectious aetiology? DD Today Dis Mech 2(3):345-349

Moelants EA, Van Damme J, Proost P (2011) Detection and quantification of citrullinated chemokines. PLoS ONE 6(12):e8976

Morseman JP, Moss MW, Zoha SJ and. Allnutt FCT (1999) PBXL-1: a new fluorochrome applied to detection of proteins on membranes. Biotechniques 26:559-563

Op De Beeck K, Vermeersch P, Verschueren P, Westhovens R, Mariën G, Blockmans D, Bossuyt X (2011) Detection of antinuclear antibodies by indirect immunofluorescence and by solid phase assay. Autoimmun Rev 10(12):801-808

Pincus T, Sokka T (2009) Laboratory tests to assess patients with rheumatoid arthritis: advantages and limitations. Rheum Dis Clin N Am 35(4):731-734, vi-vii

Preussmann R, Schneider H, Epple F (1969) Detection of alkylating agents. II Detection of different class of alkylating agents by a modification of the color reaction with 4-(4'nitrobenzyl)pyridine (NBP) Arzneim. Forsch 19:1059-1073

Rashid T, Jayakumar KS, Binder A, Ellis S, Cunningham P, Ebringer A (2007) Rheumatoid arthritis patients have elevated antibodies to cross-reactive and non-cross-reactive antigens from Proteus microbes. Clin Exp Rheumatol 25(2):259-267

Reimer U, Reineke U, Schutkowski M (2011) Peptide arrays for the analysis of antibody epitope recognition patterns. Mini-Rev Org Chem 8:137-146

Reineke U, Volkmer-Engert R, Schneider-Mergener J (2001) Applications of peptide arrays prepared by the SPOT-technology. Curr Opin Biotechnol 12:59-64

Salamunić I (2010) Laboratory diagnosis of autoimmune diseasesnew technologies, old dilemmas. Biochem Med 20(1):45-56

Schur PH (2005) Anti-cyclic citrullination peptide antibodies: diagnostic, predictive and monitoring value in RA. Int J Adv Rheumatol 3:77-83

Silman AJ, Pearson JE (2002) Epidemiology and genetics of rheumatoid arthritis. Arthritis Res 4(3):265-272

Somers K, Geusens P, Elewaut D, De Keyser F, Rummens JL, Coenen M, Blom M, Stinissen P, Somers V (2011) Novel autoantibody markers for early and seronegative rheumatoid arthritis. J Autoimmun 36(1):33-46

Tiwana H, Wilson C, Alvarez A, Abuknesha R, Bansal S, Ebringer A (1999) Cross-reactivity between the rheumatoid arthritis-associated motif EQKRAA and structurally related sequences found in Proteus mirabilis. Infect Immun 67(6):2769-2775

van Eden W, van der Zee R, van Kooten P, Berlo SE, Cobelens PM, Kavelaars A, Heijnen CJ, Prakken B, Roord S, Albani S (2002) Balancing the immune system: Th1 and Th2. Ann Rheum Dis 61:25-28

Wilson C, Ebringer A, Ahmadi K, Wrigglesworth J, Tiwana H, Fielder M, Binder A, Ettelaie C, Cunningham P, Joannou C (1995) Shared amino acid sequences between major histocompatibility complex class II glycoproteins, type XI collagen and Proteus mirabilis in rheumatoid arthritis. Ann Rheum Dis 54(3):216-220

Wilson C, Tiwana H, Ebringer A (2000) Molecular mimicry between HLA-DR alleles associated with rheumatoid arthritis and Proteus mirabilis as the aetiological basis for autoimmunity. Microbes Infect 2(12):1489-1496

Publisher's Note Springer Nature remains neutral with regard to jurisdictional claims in published maps and institutional affiliations. 